\title{
Pargasite at high pressure and temperature
}

Davide Comboni ${ }^{1}$, Paolo Lotti ${ }^{1,2^{*}}$, G. Diego Gatta ${ }^{1,3}$, Marco Merlini ${ }^{1}$, Hanns-Peter Liermann ${ }^{4}$ and Daniel J. Frost ${ }^{5}$

\author{
${ }^{1}$ Dipartimento di Scienze della Terra, Università degli Studi di Milano, \\ Via Botticelli 23, I-20133 Milano, Italy \\ ${ }^{2}$ ELETTRA Sincrotrone Trieste S.c.P.A., Strada Statale 14, km. 163.5, 34149 Basovizza, Trieste, \\ Italy \\ ${ }^{3} \mathrm{CNR}$ - Istituto di Cristallografia, Sede di Bari, Via G. Amendola 122/O, Bari, Italy \\ 4 Photon Sciences, DESY, Notkestrasse 85, D-22607 Hamburg, Germany \\ ${ }^{5}$ Bayerisches Geoinstitute, University of Bayreuth, D-95440 Bayreuth, Germany
}

*Corresponding Author: Dr. Paolo Lotti

Phone: +39-02-50315598, Fax: +39-02-50315597, e-mail: paolo.lotti@unimi.it

Manuscript to be submitted to Physics and Chemistry of Minerals 


\section{Abstract}

The $P$ - $T$ phase stability field, the thermo-elastic behavior and the $P$-induced compression mechanisms at the atomic scale of pargasite crystals from the "phlogopite peridotite unit" of the Finero mafic-ultamafic complex (Ivrea-Verbano Formation, Italy) have been investigated by a series of in-situ experiments: $a$ ) at high pressure (up to $20.1 \mathrm{GPa}$ ), by single-crystal synchrotron Xray diffraction with a diamond anvil cell, $b$ ) at high temperature (up to $823 \mathrm{~K}$ ), by powder synchrotron X-ray diffraction using a hot air blower device, and $c$ ) at simultaneous $\mathrm{H} P$-HT conditions, by single-crystal synchrotron X-ray diffraction with a resistive-heated diamond anvil cell $\left(P_{\max }=16.5 \mathrm{GPa}, T_{\max }=1200 \mathrm{~K}\right)$. No phase transition has been observed within the $P-T$ range investigated. At ambient $T$, the refined compressional parameters, calculated by fitting a secondorder Birch-Murnaghan Equation of State $(\mathrm{BM}-\mathrm{EoS})$, are: $V_{0}=915.2(8) \AA^{3}$ and $K_{\mathrm{P} 0, \mathrm{~T} 0}=95(2) \mathrm{GPa}$ $\left(\beta_{\mathrm{P} 0, \mathrm{~T} 0}=0.0121(2) \mathrm{GPa}^{-1}\right)$ for the unit cell volume; $a_{0}=9.909(4) \AA$ and $K(a)_{\mathrm{P} 0, \mathrm{~T} 0}=76(2) \mathrm{GPa}$ for the $a$-axis; $b_{0}=18.066(7) \AA$ and $K(b)_{\mathrm{P} 0, \mathrm{~T} 0}=111(2) \mathrm{GPa}$ for the $b$-axis; $c_{0}=5.299(5) \AA$ and $K(c)_{\mathrm{P} 0, \mathrm{~T} 0}=$ 122(12) $\mathrm{GPa}$ for the $c$-axis $\left[K(c)_{\mathrm{P} 0, \mathrm{~T} 0} \sim K(b)_{\mathrm{P} 0, \mathrm{~T} 0}>K(a)_{\mathrm{P} 0, \mathrm{~T} 0}\right]$. The high-pressure structure refinements (at ambient $T$ ) show a moderate contraction of the $\mathrm{TO}_{4}$ double chain and a decrease of its bending in response to the hydrostatic compression, along with a pronounced compressibility of the $\mathrm{A}$ - and $\mathrm{M}(4)$-polyhedra $\left[K_{\mathrm{P} 0, \mathrm{~T} 0}(\mathrm{~A})=38(2) \mathrm{GPa}, K_{\mathrm{P} 0, \mathrm{~T} 0}(\mathrm{M} 4)=79(5) \mathrm{GPa}\right]$ if compared to the $\mathrm{M}(1)-, \mathrm{M}(2)-, \mathrm{M}(3)$-octahedra $\left[K_{\mathrm{P} 0}, \mathrm{~T} 0(\mathrm{M} 1,2,3) \leq 120 \mathrm{GPa}\right]$ and to the rigid tetrahedra $\left[K_{\mathrm{P} 0, \mathrm{~T} 0}(\mathrm{~T} 1, \mathrm{~T} 2)\right.$ $\sim 300 \mathrm{GPa}$. The thermal behavior, at ambient pressure up to $823 \mathrm{~K}$, was modelled with Berman's formalism, which gives: $V_{0}=909.1(2) \AA^{3}, \alpha_{0}=2.7(2) \cdot 10^{-5} \mathrm{~K}^{-1}$ and $\alpha_{1}=1.4(6) \cdot 10^{-9} \mathrm{~K}^{-2}$ [with $\alpha_{0}(a)=$ $0.47(6) \cdot 10^{-5} \mathrm{~K}^{-1}, \alpha_{0}(b)=1.07(4) \cdot 10^{-5} \mathrm{~K}^{-1}$, and $\left.\alpha_{0}(c)=0.97(7) \cdot 10^{-5} \mathrm{~K}^{-1}\right]$. The petrological implications of the experimental findings of this study are discussed.

Keywords: pargasite, amphibole, high pressure, high temperature, phase stability, synchrotron Xray diffraction 


\section{Introduction}

Amphiboles are an important supergroup of rock-forming minerals, with an unusually high chemical variability and the ability to crystallize under almost all conditions relevant to the petrogenesis of crustal or upper mantle rocks, as well as subducting slabs (e.g., Robinson et al. 1982, Green and Wallace 1988, Hawthorne 1981). This chemical diversity originates from their structure, which is able to accommodate almost all the elements of the periodic table (Hawthorne and Oberti 2007). In particular, the occurrence of hydroxyl groups into the structure has proved to be a significant agent in the water cycle within the upper mantle (e.g., Gill 1981). Amphiboles crystallise from basaltic magmas at mid ocean ridges and are eventually dragged into the upper mantle at subduction zones. During subduction, many hydrous minerals become unstable and water is released, migrating into the overlying and much hotter mantle wedge, causing melting and arc volcanism as e.g. described for the case of talc (Bose and Ganguly 1989). In order to better understand the water cycle in the upper and potentially lower mantle, it is essential to determine the stability of all hydrous minerals subducted into the mantle. Because amphiboles are volumetrically the most abundant hydrous minerals in the lithospheric mantle, they play an important role in a number of metasomatic and metamorphic processes (e.g., Wallace and Green 1991; Ionov and Hofmann 1995; Vannucci et al. 1995; Niida and Green 1999; Foley et al. 2002; Ionov et al. 2002). Thus, a series of studies have been devoted to the $P-T$ stability of amphiboles in subducting slabs, and to clarifying their role in transporting hydrogen (e.g., Poli and Schmidt 1995; Schmidt and Poli 1998; Stern 2002; Forneris and Holloway 2003; Fumagalli and Poli 2005). Owing to their importance, a number of in-situ high-pressure $(\mathrm{H} P)$ and high-temperature $(\mathrm{H} T)$ studies have been performed in order to describe the $P-T$ stability fields, the thermo-elastic behavior and the $P$ - or $T$ induced deformation mechanisms of amphiboles at the atomic scale. Comodi et al. (1991) reported the compressibility of tremolite, pargasite and glaucophane on the basis of in-situ single-crystal Xray diffraction experiments with a diamond anvil cell (DAC) up to about $4 \mathrm{GPa}$. The 
compressibility of grunerite was investigated by Zhang et al. (1992) up to 5 GPa (single-crystal Xray diffraction experiment with a DAC). Yang et al. (1998) reported the compressional behavior and the $P$-induced $C 2 / m-P 2{ }_{1} / m$ phase transition (at about $1.2 \mathrm{GPa}$ ) in cummingtonite, by in-situ Xray and infra-red experiments with a DAC. Later, Boffa Ballaran et al. (2000) investigated the HP transformation behavior of the cummingtonite-grunerite solid solution (single-crystal X-ray diffraction experiments with a DAC). Comodi et al. (2010) reported the compressional behavior of two kaersutites up to $8 \mathrm{GPa}$, highlighting the role of the oxo-component on the elastic behavior of amphiboles (single-crystal X-ray diffraction experiments using a DAC). Jenkins et al. (2010) reported the compressibility of glaucophane based on an in-situ X-ray powder diffraction experiment compressed within DAC up to $10 \mathrm{GPa}$. Zanazzi et al. (2010) investigated the highpressure behavior of a crystal of protomangano-ferro-antophyllite up to $9 \mathrm{GPa}$ with a DAC. Welch et al. (2011a) described the elastic behavior of a Mg-rich antophyllite and its deformation mechanisms at the atomic scale up to $7 \mathrm{GPa}$, by in-situ single-crystal X-ray diffraction with a DAC. The compressional behavior of gedrite up to $7 \mathrm{GPa}$ was later reported by Nestola et al. (2012) (single-crystal X-ray diffraction experiments with a DAC). More recently, Thompson et al. (2016) investigated the relation between the frequency of $\mathrm{O}-\mathrm{H}$ bonds stretching modes and the hydrogen bond symmetrization induced by pressure. The elastic parameters obtained by the aforementioned experiments are listed in Table 1. However, as pointed out in Welch et al. (2007), there is a need to extend the compressibility measurement to $P$ higher than $10 \mathrm{GPa}$, in order to improve the accuracy of the refined isothermal bulk modulus values and their $P$-derivatives.

A series of in-situ experiments have been performed on the low and high thermal behavior of amphiboles, on the basis of several experimental techniques (e.g., Sueno et al. 1978; Cameron et al. 1983; Cámara et al. 2003, 2007; Iezzi et al. 2005a; Jenkins and Corona 2006), reviewed by Welch et al. (2007). Some more recent studies are, e.g., those of Tribaudino et al. (2008), Welch et al. (2008) and Iezzi et al. (2011) on richterite, Welch et al. (2011b) on anthophyllite and Zema et al. (2012) on gedrite. 
Neutron diffraction experiments at low- and room- $T$ aimed to describe the atomic site ordering and the H-bonding scheme in amphiboles have also been performed (e.g., Welch and Knight 1999; Iezzi et al. 2005b; Gatta et al. 2017).

To the best of our knowledge, no simultaneous in-situ $P-T$ studies have been conducted on amphiboles. This lack of knowledge prevents a detailed description of the behavior of amphiboles that are stable at $\mathrm{H} P-\mathrm{H} T$ conditions and consequently it is still difficult to assess their petrological implications.

As pointed out by Niida and Green (1999), pargasite is recognized as a ubiquitous hydrous de-hydroxilation phenomenon, and $c$ ) its phase stability field at simultaneous $\mathrm{H} P$-HT conditions. phase in the Earth's upper mantle. In this light, we have selected crystals of pargasite from the peridotite of the "phlogopite peridotite unit" of the Finero mafic-ultamafic complex (Ivrea-Verbano Formation, Italy) (Cawthorn 1975; Rivalenti et al. 1975, 1984; Coltorti and Siena 1984; Siena and Coltorti 1989), in order to describe: $a$ ) the $\mathrm{H} P$ elastic behavior of this amphibole (at $P>4 \mathrm{GPa}$ ) and its main compression mechanisms at the atomic scale, $b$ ) its $\mathrm{H} T$ behavior, along with its potential

\section{Structure of pargasite}

Pargasite is a Ca-amphibole associated to medium- or high-pressure/high-temperature conditions. On the basis of the general amphibole formula $\mathrm{A}_{0-1} \mathrm{~B}_{2} \mathrm{C}_{5} \mathrm{~T}_{8} \mathrm{O}_{22} \mathrm{~W}_{2}$ (Hawthorne and Oberti 2007), the ideal chemical formula of pargasite can be written as: ${ }^{\mathrm{A}} \mathrm{Na}^{\mathrm{B}} \mathrm{Ca}_{2}{ }^{\mathrm{C}}\left(\mathrm{Mg}_{4} \mathrm{Al}\right)^{\mathrm{T}}\left(\mathrm{Si}_{6} \mathrm{Al}_{2}\right) \mathrm{O}_{22}{ }^{\mathrm{W}}(\mathrm{OH})_{2}$. Its structure, described in the space group $C 2 / m$, is characterized by double chains of $\mathrm{TO}_{4}$ tetrahedra running parallel to [001] (Fig. 1). In each chain, there are two distinct $\mathrm{TO}_{4}$ tetrahedra (with two crystallographically independent $\mathrm{T}(1)$ and $\mathrm{T}(2)$ sites). The $\mathrm{TO}_{4}$ tetrahedra are connected in such a way that an alternation of pseudo-hexagonal rings, delimitated by six $\mathrm{TO}_{4}$ units, occurs (Fig. 1). On the basis of single-crystal X-ray diffraction experiments, Papike at al. (1969) observed the preference of $\mathrm{Al}$ for the T(1) site. This finding was 
later confirmed by Welch and Knight (1999) on the basis of a neutron diffraction experiment on a synthetic pargasite. Hawthorne and Oberti (2007) showed that the $\langle T$-O $\rangle$ distance varies linearly with the $\mathrm{Al}$ content, when the $\mathrm{Al}$ fraction is higher than 0.50 atoms per formula unit (apfu); furthermore, Hawthorne and Oberti (2007) proposed an equation in which the fraction of $\mathrm{Al}$ is correlated to the average $\langle T-\mathrm{O}\rangle$ bond length. The topological configuration of the double silicate chains of the octahedral sites (with three crystallographically independent positions $M(1), M(2)$ and $\mathrm{M}(3)$, i.e., the $\mathrm{C}$ sites of the general amphibole formula), of the 8-fold site $\mathrm{M}(4)$ (i.e., the $\mathrm{B}$ site) and of the A site are shown in Figs. 1 and 2. The $\mathrm{M}(1), \mathrm{M}(2)$ and $\mathrm{M}(3)$ sites are occupied mainly by $\mathrm{Mg}$ and, in lower fractions, by other cations including: $\mathrm{Fe}^{2+}, \mathrm{Mn}^{2+}, \mathrm{Fe}^{3+}, \mathrm{Al}$, and $\mathrm{Ti}^{4+}$. The $\mathrm{M}(4)$ site is occupied by $\mathrm{Ca}, \mathrm{Na}, \mathrm{Mg}$, and $\mathrm{Fe}^{2+}$. The A sites can be vacant or occupied by $\mathrm{Na}^{+}\left(\right.$and $\left.\mathrm{K}^{+}\right)$.

\section{Experimental methods}

Several crystals of pargasite from the same rock sample of the "phlogopite peridotite unit", Finero mafic-ultramafic complex (Ivrea-Verbano Formation, Italy), were selected on the basis of optical and X-ray diffraction quality. Preliminary single-crystal X-ray diffraction experiments, aimed to select the best crystals, were performed using a KUMA-KM4 four-circle diffractometer (equipped with point-detector and $\mathrm{MoK \alpha}$ radiation) at the Earth Science Department - University of Milano (ESD-MI). The chemical composition of the pargasite crystals was determined by electronmicroprobe analysis in wavelength dispersive mode (EPMA-WDS), using a Jeol JXA-8200 microprobe at the ESD-MI. The system was operated with an accelerating voltage of $15 \mathrm{kV}$, a beam current of $5 \mathrm{nA}$, a counting time of $30 \mathrm{~s}$ on the peaks and $10 \mathrm{~s}$ on the backgrounds and a beam diameter of $10 \mu \mathrm{m}$. Minerals (graftonite for $\mathrm{Fe}$ and $\mathrm{Mn}$; grossular for $\mathrm{Si}, \mathrm{Al}$ and $\mathrm{Ca}$; K-feldspar for $\mathrm{K}$; forsterite for $\mathrm{Mg}$; rutile for $\mathrm{Ti}$; omphacite for $\mathrm{Na}$; and hornblende for $\mathrm{F}$ ) were used as standards. The raw data were corrected for matrix effects using the $\varphi \rho \mathrm{Z}$ method as implemented in the JEOL suite of programs. Crystals were found chemically homogeneous. The average anhydrous chemical formula (40 points analysis), calculated on the basis of 23 oxygen atoms is: 
$\mathrm{Na}_{0.60} \mathrm{~K}_{0.15} \mathrm{Ca}_{1.80} \mathrm{Mn}_{0.01} \mathrm{Cr}_{0.24} \mathrm{Fe}_{0.39} \mathrm{Mg}_{4.10} \mathrm{Ti}_{0.05} \mathrm{Al}_{1.62} \mathrm{Si}_{6.71} \mathrm{O}_{23}$; the structural formula is

${ }^{\mathrm{A}}\left(\mathrm{Na}_{0.52} \mathrm{~K}_{0.15}\right)^{\mathrm{B}}\left(\mathrm{Mg}_{0.11} \mathrm{Mn}_{0.01} \mathrm{Ca}_{1.80} \mathrm{Na}_{0.08}\right)^{\mathrm{C}}\left(\mathrm{Al}_{0.33} \mathrm{Ti}_{0.05} \mathrm{Cr}_{0.24} \mathrm{Fe}_{0.39} \mathrm{Mg}_{3.99}\right)^{\mathrm{T}}\left(\mathrm{Al}_{1.29} \mathrm{Si}_{6.71}\right) \mathrm{O}_{22}{ }^{\mathrm{W}}(\mathrm{OH})_{2}$, assuming $\mathrm{H}_{2} \mathrm{O}$ content by stoichiometry (crystals are F-free).

The $\mathrm{H} P$-and the $\mathrm{H} P$-HT synchrotron X-ray single-crystal diffraction experiments were conducted at the Extreme Conditions Beamline P02.2 at PETRA-III/DESY, Hamburg, Germany, using fragments of one of the crystals previously checked by single-crystal X-ray diffraction and EPMA-WDS at the ESD-MI. Data collections were performed with an incident beam of $42.7 \mathrm{keV}$ in energy $(\lambda=0.2904 \AA)$, and a focusing spot of $\sim 8.5(\mathrm{H}) \mu \mathrm{m} \times 1.8(\mathrm{~V}) \mu \mathrm{m}$ originated from a compound refractive lenses system, consisting of 110 Be lenses with a radius of $50 \mu \mathrm{m}(400 \mu \mathrm{m}$ beam acceptance) and a focal length of $1221 \mathrm{~mm}$. A single crystal of pargasite $\left(\sim 20 \times 30 \times 40 \mu \mathrm{m}^{3}\right)$ equipped with Boehler-Almax design diamonds/seats with a $70^{\circ}$ opening and $300 \mu \mathrm{m}$ culets size. A $250 \mu \mathrm{m}$ thick rhenium gasket was pre-indented to $50 \mu \mathrm{m}$ and then drilled with $200 \mu \mathrm{m}$ hole, in which the crystal of pargasite, along with some ruby spheres for pressure determination (Mao et al. 1986), were located. Neon was used as a hydrostatic pressure-transmitting medium (Angel et al. 2007; Klotz et al. 2009). Pressure was increased with an automated pressure-driven membrane system and measured with the online ruby/alignment system. Diffraction data were successfully collected up to $20.1 \mathrm{GPa}$; at higher pressure the crystal was irredeemably damaged by bridging between the two diamonds.

A modified 4 pin DAC, equipped with a graphite resistive heater (modified version of the indented to $50 \mu \mathrm{m}$ and then drilled with a $200 \mu \mathrm{m}$ diameter hole, in which the crystal of pargasite, together with some ruby chips and a gold fragment ( 20 $\mu \mathrm{m}$ thick) as pressure standards, were 
vacuum vessel allowed the collection of single crystal data during two $T$-ramps performed at pressures of $\sim 7.5$ and $\sim 16.5 \mathrm{GPa}$, respectively. The unit-cell parameters of gold were determined by the least-squares refinement of the (111), (200), and (220) diffraction lines. The temperature in the pressure chamber was controlled using a $\mathrm{Pt}: \mathrm{Pt}-\mathrm{Rh}$ thermocouple, and the actual pressure at each point was determined according to the $P-T-V$ equation of state of gold of Fei et al. (2007).

For both the single-crystal $\mathrm{H} P$ and $\mathrm{H} P-\mathrm{H} T$ experiments, diffraction patterns were acquired on a PerkinElmer XRD 1621 flat panel detector, using an in house script for collecting step-scan diffraction images. Sample to detector distance was calibrated using a $\mathrm{CeO}_{2}$ standard (NIST 674a). The diffraction images were then converted to conform to the "Esperanto" format of the program CrysAlis (Agilent Technologies 2011; Rothkirch et al. 2013). At all the pressure points, the adopted data collection strategy consisted of a pure $\omega$-scan $\left(-30^{\circ} \leq \omega \leq+30^{\circ}\right)$, with a step size of $1^{\circ}$ and an exposure time of $1 \mathrm{~s} /$ frame; then Bragg peaks were indexed. Intensities of the diffraction peaks were integrated and corrected for Lorentz-polarization effects, using the CrysAlis package (Agilent Technologies 2011). Scaling and correction for absorption (due to the DAC components) was applied by the semi-empirical $A B S P A C K$ routine implemented in CrysAlis. The refined unit-cell parameters of the $\mathrm{H} P$ and $\mathrm{H} P-\mathrm{H} T$ experiments are listed in Table 2 and Table 3, respectively. No evidence of phase transitions was observed within the $P$ - and $P$ - $T$-ranges investigated; all the diffraction patterns were successfully indexed in the $C 2 / m$ space group.

In-situ HT powder diffraction data of pargasite were collected at the MCX beamline at ELETTRA (Trieste, Italy), using the high-resolution diffractometer available at the station (Rebuffi et al. 2014). The sample was loaded in a quartz capillary. High temperature was generated with a hot air blower device, and temperature was monitored with a thermocouple and calibrated against thermal expansion and phase transition of quartz. Monochromatic radiation $(\lambda=0.8202 \AA)$ was used. Diffraction data were collected up to $823 \mathrm{~K}$. The diffraction patterns were treated by Le Bail full-profile fit (Le Bail et al. 1988), using the GSAS package (Larson and Von Dreele 1994), aimed to obtain the unit-cell parameters only. All diffraction patterns were fitted using the pseudo-Voigt 
profile function of Thompson et al. (1987); the background curves were modelled with a Chebyshev polynomial. The refined unit-cell parameters are listed in Table 4; the evolution of the unit cell parameters with $T$ is shown in Fig. 3 .

\section{Structure refinement protocol}

All the structure refinements, based on the intensity data of the $\mathrm{H} P$ experiment (at room- $T$ ), were performed using the software JANA2006 (Petříček et al. 2014), starting from the structure model of Hawthorne et al. (1996), in the space group $C 2 / m$. Reflections with an interplanar distance $d \leq 0.8 \AA$ were excluded. In order to reduce the number of variables to refine, the sites were modelled as follows: $\mathrm{T}(1)$ and $\mathrm{T}(2)$ sites were modelled as fully occupied by $\mathrm{Si}$; the $\mathrm{M}(1)$ site populated by Mg only; the $\mathrm{M}(2)$ was modelled with a mixed $(\mathrm{Mg}+\mathrm{Cr}) \mathrm{X}$-ray scattering curve; the $\mathrm{M}(3)$ site populated by $\mathrm{Mg}$ only; the $\mathrm{M}(4)$ site populated by $(\mathrm{Ca}+\mathrm{Na})$; the partially occupied A site (located at $0,0.48,0)$ was modelled with a mixed $(\mathrm{K}+\mathrm{Na})$ scattering curve. In all the refinements, some restraints were applied: the $\mathrm{T}(1)$ and $\mathrm{T}(2)$ sites were refined with the same isotropic displacement parameter $\left(U_{\text {iso }}\right)$, and the same strategy was applied for all the oxygen sites $(\mathrm{O} 1, \mathrm{O} 2$, O3, O4, O5, O6, O7); the $\mathrm{M}(1), \mathrm{M}(2)$ and $\mathrm{M}(3)$ sites were modelled with a fixed $U_{\text {iso }}$ equal to 0.006 $\AA^{2}$.

The principal statistical parameters of the structure refinements are listed in Table 5 (deposited). Atomic coordinates and site occupancies of selected structure refinements are given in Table 6 (deposited). The relevant bond distances related to the $M(4)$ and A sites are reported in Table 7. Other relevant structural parameters are listed in Table 8.

\section{Results}

- Compressional behavior 
The $P$-induced evolution of the unit-cell parameters of pargasite up to $20.1 \mathrm{GPa}$ is shown in Fig.

4. The experimental $P-V$ data have been best fitted using the (isothermal) Birch-Murnaghan Equation of State (BM-EoS), which is based on the assumption that the strain energy of a solid undergoing compression can be expressed as a Taylor series in the finite Eulerian strain. The equation has the following form:

$$
P=3 / 2 K_{\mathrm{P} 0, \mathrm{~T} 0}\left[\left(V_{0} / V\right)^{7 / 3}-\left(V_{0} / V\right)^{5 / 3}\right]\left\{1-3 / 4\left(4-3 / 2 K_{\mathrm{P} 0, \mathrm{~T} 0}^{\prime}\right)\left[\left(V_{0} / V\right)^{2 / 3}-1\right]\right\}+\ldots
$$

where $K_{\mathrm{P} 0, \mathrm{~T} 0}$ is the bulk modulus at ambient conditions $\left(K_{\mathrm{P} 0, \mathrm{~T} 0}=-V_{0}(\partial P / \partial V)_{\mathrm{P} 0, \mathrm{~T} 0}=1 / \beta_{\mathrm{P} 0, \mathrm{~T} 0}\right.$, where $\beta_{\mathrm{P} 0, \mathrm{T0}}$ is the volume compressibility coefficient at ambient conditions) and $K^{\prime}{ }^{\prime} 0, \mathrm{~T} 0$ is its $P$-derivative. Truncated to the second order (in energy), $K_{\mathrm{P} 0, \mathrm{~T} 0}^{\prime}$ is fixed to 4 . The least squares fit was performed using the EoSFit 7.0 software (Angel et al. 2000, 2014), with data weighted by the uncertainties in $P$ and $V$ (Table 9). An apparent change in the volume compressional behavior of pargasite can be observed between 6.53 and $7.20 \mathrm{GPa}$ (Fig. 4). In this light, two different Birch-Murnaghan equations of state, truncated to the second order, have been fitted to the experimental data within the $P$-ranges $0.0001-6.53 \mathrm{GPa}$ and 7.20-20.14 GPa, respectively. The refined elastic parameters are: $V_{0}$ $=915.2(8) \AA^{3}$ and $K_{\mathrm{P} 0, \mathrm{~T} 0}=95(2) \mathrm{GPa}$ for the low $-P$ range; $V_{0}=907(1) \AA^{3}$ and $K_{\mathrm{P} 0, \mathrm{~T} 0}=111(2) \mathrm{GPa}$ for the high- $P$ range (Table 9).

The axial compressibilities were calculated within the range 0.0001-6.53 GPa, using the "linearized" second-order BM-EoS (Angel 2000), and the least squares fits were performed accounting for uncertainties in $P$ and length (Table 9). The relatively high e.s.d. on the elastic parameter of the $c$ axis is probably due to the orientation of the crystal in the pressure chamber. Pargasite shows a significant anisotropic compressibility with $K(c)_{\mathrm{P} 0, \mathrm{~T} 0} \sim K(b)_{\mathrm{P} 0, \mathrm{~T} 0}>K(a)_{\mathrm{P} 0, \mathrm{~T} 0}(\mathrm{Table}$

9). The change of the volume compressional behavior is coupled with the change of the high- $P$ behavior of the monoclinic $\beta$ angle above $7 \mathrm{GPa}$, which increases its value with $P$ reaching a saturation at $P>12 \mathrm{GPa}$ (Fig. 4). 


\section{- Thermal expansion}

The unit-cell volume variation as a function of $T$ exhibits a continuous trend up to $823 \mathrm{~K}$, as shown in Fig. 3. Within the $T$-range investigated, the volume thermal expansion coefficient $\alpha_{\mathrm{T}}$ increases approximately linearly with temperature. $T$ - $V$ fits to different thermal equations were performed. The best fit was obtained with the (isobaric) equation reported by Berman (1988):

$$
V_{\mathrm{T}}=V_{0}\left[1+\alpha_{0}\left(T-T_{0}\right)+1 / 2 \alpha_{1}\left(T-T_{0}\right)^{2}\right] \text {, }
$$

where the parameter $\alpha_{0}$ is the thermal expansion coefficient at $T_{0}$ (and $P_{0}$ ). Given the small changes in volume with temperature, the thermal expansion coefficient at high- $T$ can be expressed as: $\alpha_{\mathrm{T}} \approx$ $\left[\alpha_{0}+\alpha_{1}\left(T-T_{0}\right)\right]$. The refined parameters for the unit-cell volume are: $\alpha_{0}=2.7(2) \cdot 10^{-5} \mathrm{~K}^{-1}$ and $\alpha_{1}=$ $1.4(6) \cdot 10^{-9} \mathrm{~K}^{-2}$. The thermal expansion of pargasite is anisotropic with $\alpha_{0}(b) \sim \alpha_{0}(c)>\alpha_{0}(a)$ (Table 10). No evidence for a phase transition was observed within the $T$-range investigated.

\section{- $\quad P$ - $T$ - phase stability}

During the two $P$ - $T$ ramps, no evidence of phase transition (e.g., no reflections violating the $C 2 / m$ extinction conditions, which would be indicative of a transformation to $P 2_{1} / m$, as observed e.g. in cummingtonite, Yang et al. 1988) or de-hydroxilation was observed. It is worth to note that every data collection was performed after at least 20 minutes of equilibration at any given $P-T$ condition. However, since the pargasite structure could be metastable at the highest $P-T$ here investigated, the sample was kept for 40 minutes at $T>1161(2) K$ before the last data collection. Even in this case, no reflections violating the $C 2 / m$ symmetry were detected, suggesting that the pargasite structure is stable within the entire $P-T$ range investigated. The temperature was then progressively decreased down to ambient- $T$ and, after 150 minutes, a data collection at ambient temperature and 9.4(3) GPa was performed: the structure refinement showed that any $P$ - $T$ effect on the structure of pargasite was fully reversible after $T$ release. 


\section{- Pressure-induced structural evolution}

The most significant changes of the $(\mathrm{Si}, \mathrm{Al}) \mathrm{O}_{4}$ double chains, in response to the applied pressure, can be described in terms of the O-O-O inter-tetrahedral angle variation (Fig. 1). As pressure increases, the kinking of the $\mathrm{TO}_{4}$ tetrahedra causes a decrease of O6-O5-O7 and O6-O7-O6 (Fig. 5). relation (i.e., if the first decreases, the second increases) (Table 11). These $P$-induced mechanisms affect the diameters of the pseudo-hexagonal rings confined by the double silicate chains. The diameters $\mathrm{O} 7-\mathrm{O} 7$ and O6-O6 decrease by about 3\% and 6.5\%, respectively, from P3 (1.99 GPa) to $P 19$ (20.14 GPa). On the contrary, the distance O5-O5 remains practically constant within $2 \sigma$ (Fig. 6). The kinking of the tetrahedral units of the chains leads to the closure of the O6-O5-O6 angle. This is the main effect that leads to the contraction of the $\mathrm{TO}_{4}$ double chain (Fig. 2). One of the further structural effects in response to hydrostatic compression is the reduction of the tetrahedral double-chain bowing, towards a flat configuration at high pressure. Such a behavior can be described, for example, on the basis of the difference between the atomic $x$ coordinates of the $\mathrm{O} 4$ and $\mathrm{O} 7$ oxygen atoms (i.e., $\Delta x(\mathrm{O} 4-\mathrm{O} 7) \cdot a(\AA))$, as shown in Fig. 7 and Table 12: the bowing decreases with $P$, and approaches a flat configuration (with $\Delta x(\mathrm{O} 4-\mathrm{O} 7) \cdot a=0$ ) at about 15-16 GPa. At the same pressures, we observe the saturation effect on the $P$-induced evolution of other structural parameters, e.g., O6-O5-O7, O5-O6-O7, O5-O7-O5, O6-O7-O6 and the $\beta$ angle behavior (Fig. 4).

The volumes of the $\mathrm{TO}_{4}$ polyhedra, reported in Table 13, do not show substantial variations within the $P$-range investigated, suggesting that the $\mathrm{TO}_{4}$ tetrahedra behave, at a first approximation, as rigid units (with bulk moduli of about $300 \mathrm{GPa}$, Table 14). The distorted polyhedra coordinated by the A site is the softest one, with a bulk modulus, calculated with a second-order BM-EoS, of 38(2) GPa, followed by M(4) (bulk modulus 79(5) GPa). The M(1)-, M(2)- and M(3)-octahedra are 
stiffer than A- and M(4)polyhedra, with bulk moduli respectively of 120(11), 107(14) and 108(18) GPa (Table 14).

\section{Discussion}

This is the first study in which the compressional behavior of paragasite is described at pressures up to $\sim 20 \mathrm{GPa}$, its thermal behavior up to $823 \mathrm{~K}$, and its thermo-elastic behavior under the combined effect of $P$ and $T$ by in-situ experiments.

The isothermal bulk modulus of pargasite obtained in this study (i.e., $K_{\mathrm{P} 0, \mathrm{~T} 0}=95(2) \mathrm{GPa}$ for $P \leq 6.53 \mathrm{GPa}$ and $K_{\mathrm{P} 0, \mathrm{~T} 0}=111(2) \mathrm{GPa}$ for $\left.P \geq 7.20 \mathrm{GPa}\right)$ is among the highest found so far for amphiboles, ranging between 50 and $100 \mathrm{GPa}$ (Table 1; Comodi et al. 1991, 2010; Zhang et al. 1992; Yang et al. 1998; Boffa Ballaran et al. 2000; Welch et al. 2007, 2011a; Zanazzi et al. 2010; Nestola et al. 2012). The axial bulk moduli show that the stiffest crystallographic directions of pargasite are [010] and [001], whereas [100] is the softest one, as $K(c)_{\mathrm{P} 0, \mathrm{~T} 0} \sim K(b)_{\mathrm{P} 0, \mathrm{~T} 0}>K(a)_{\mathrm{P} 0, \mathrm{~T} 0}$ (Table 9). This elastic anisotropy can be explained, at the atomic scale, on the basis of the structural refinements of this study:

- The tetrahedral double chains lie on the $b c$ plane. The $\mathrm{TO}_{4}$ tetrahedra behave, at a first approximation, as uncompressible units (Table 14). The principal effect, in response to the hydrostatic compression, is the kinking of the $\mathrm{TO}_{4}$ units of the tetrahedral doublechain, with the closure of the O6-O5-O6 angle and the consequent (moderate) contraction of the chains along [001] (Fig. 5, Table 11). This mechanism is common among inosilicates. In addition, the configuration of the double chain, with the sixmembered rings of tetrahedra (Fig. 1), hinders the contraction along [010], making the compression along [010] similar to that along [001].

- Along [100], the effects of pressure are mainly accommodated by the compression of the M(1)-, M(2)-, and M(3)-octahedra, M(4)- and A-polyhedra, which are drastically softer than the $\mathrm{TO}_{4}$ units (Fig. 2, Table 14). Their bonding configuration and, in general, the 
high compressibility of the $\mathrm{M}(4)$ and A-polyhedra govern the axial compressibility of the pargasite structure along [100], making the compression along this direction significantly higher than those along [010] and [001]. The compression and deformation of the A- and $\mathrm{M}(4)$-polyhedra are, in turn, responsible for the change of the bending of the tetrahedral double chains, as can be deduced on the basis of the evolution of the polyhedra bond distances with $P$ (Table 7, Fig. 7).

The anisotropic compressional scheme of pargasite found in this study is consistent with that previously reported by Comodi et al. (1991), based on data collected up to $4 \mathrm{GPa}$, and more in general to the elastic anisotropy found in monoclinic amphiboles (e.g., Comodi et al. 1991, 2010; Zhang et al. 1992; Yang et al. 1998; Boffa Ballaran et al. 2000; Welch et al. 2007), irrespective of their chemical composition. These findings suggest that the anisotropic compressional scheme of amphiboles is dictated by the topology of the structure, though the different compositions govern the magnitude of the volume and axial compressibilities.

The compressional anisotropy of pargasite is consistent with the thermal expansion scheme: almost identical axial expansion behaviors are observed along [010] (i.e., $\alpha_{0}(b)=1.07(4) \cdot 10^{-5} \mathrm{~K}^{-1}$ ) and [001] (i.e., $\alpha_{0}(c)=0.97(7) \cdot 10^{-5} \mathrm{~K}^{-1}$ ), which are significantly higher than that along [100] (i.e., $\left.\alpha_{0}(a)=0.47(6) \cdot 10^{-5} \mathrm{~K}^{-1}\right)$ (Table 10), with the following anisotropic scheme: $\alpha_{0}(b) \sim \alpha_{0}(c)>\alpha_{0}(a)$. In this case, data reported in the literature show that $C 2 / m$ amphiboles experience a different anisotropic thermal-elastic behavior in response to their composition or to the $T$-range investigated (i.e., the thermal expansion anisotropic scheme can change within different $T$-ranges): $\alpha_{0}(a) \sim \alpha_{0}(b)$ $>\alpha_{0}(c)$ (e.g., K-fluor-richterite, Cameron et al. 1983); $\alpha_{0}(a)>\alpha_{0}(b)>\alpha_{0}(c)$ (e.g., tremolite, Sueno et al. 1973; synthetic $\mathrm{Na}(\mathrm{LiMg}) \mathrm{Mg}_{5} \mathrm{Si}_{8} \mathrm{O}_{22}(\mathrm{OH})_{2}$, Iezzi et al. 2005a; synthetic $\mathrm{Na}(\mathrm{NaMg}) \mathrm{Mg}_{5} \mathrm{Si}_{8} \mathrm{O}_{22}(\mathrm{OH})_{2}$, Cámara et al. 2003; synthetic $\mathrm{Na}(\mathrm{NaMg}) \mathrm{Mg}_{5} \mathrm{Si}_{8} \mathrm{O}_{22} \mathrm{~F}_{2}$, Cámara et al. 2007; glaucophane, Jenkins and Corona 2006); $\alpha_{0}(b)>\alpha_{0}(a)>\alpha_{0}(c)$ (e.g., Na-fluor-richterite, Cameron et al. 1983; richterite at $T>600 \mathrm{~K}$, Tribaudino et al. 2008; synthetic $\mathrm{K}(\mathrm{NaCa})\left(\mathrm{Mg}_{2.5} \mathrm{Ni}_{2.5}\right) \mathrm{Si}_{8} \mathrm{O}_{22}(\mathrm{OH})_{2}$, Welch et al. 2008); $\alpha_{0}(b)>\alpha_{0}(c)>\alpha_{0}(a)$ (e.g., richterite at $T<$ 
$600 \mathrm{~K}$, Tribaudino et al. 2008). In addition, we observed a $T$-induced increase of the monoclinic $\beta$ angle (e.g., this study), other amphiboles showed an opposite behaviour (e.g., tremolite, Sueno et al. 1973; cummingtonite, Reece et al. 2000, 2002; synthetic $\mathrm{Na}(\mathrm{NaMg}) \mathrm{Mg}_{5} \mathrm{Si}_{8} \mathrm{O}_{22}(\mathrm{OH})_{2}$, Cámara et al. 2003; synthetic $\mathrm{Na}(\mathrm{NaMg}) \mathrm{Mg}_{5} \mathrm{Si}_{8} \mathrm{O}_{22}(\mathrm{OH}) 2$ and $\mathrm{Na}(\mathrm{LiMg}) \mathrm{Mg}_{5} \mathrm{Si}_{8} \mathrm{O}_{22}(\mathrm{OH})_{2}$, Iezzi et al. 2005a; richterite, Tribaudino et al. 2008; glaucophane, Jenkins and Corona 2006; synthetic

$\mathrm{K}(\mathrm{NaCa})\left(\mathrm{Mg}_{2.5} \mathrm{Ni}_{2.5}\right) \mathrm{Si}_{8} \mathrm{O}_{22}(\mathrm{OH})_{2}$, Welch et al. 2008). The lack of high- $T$ structural refinements in this study do not allow a description of the $T$-induced mechanisms at the atomic scale. No dehydroxilation was observed up to the maximum temperature achieved in our HT experiment (i.e., $823 \mathrm{~K})$. De-hydroxilation in amphibole was observed at $T>1000-1100 \mathrm{~K}$, at ambient $P(e . g$., Zema et al. 2012 and reference therein).

Unfortunately, because of significant $P$-fluctuations during the measurements, leading to large $P$ uncertainties, it was not possible to fit the data of the two $P$ - $T$ ramps to a thermal EoS. Attempts at correcting the $P$ estimates using different levels of approximation (i.e., using an average $P)$ do not lead to any conclusive improvements. The $\mathrm{H} P-\mathrm{H} T$ data of this study do show unambiguously, however, that pargasite is stable, in its $C 2 / m$ form, under the combined conditions of high pressure and temperature up to at least $\sim 16.5 \mathrm{GPa}$ and $\sim 1200 \mathrm{~K}$, without any evidence for de-hydroxylation within the $P-T$ range investigated. As a matter of fact, the unit cell volume of the sample employed in the highest $P-T$ ramp and then measured after $T$-release at ambient- $T$ and 9.4(3) GPa (i.e., 840(2) $\AA^{3}$ ), is virtually identical to the volume of the sample used for the HP experiment at the same $P$-condition (i.e., $840.0(6) \AA^{3}$ at $9.74(5) \mathrm{GPa}$ ); in addition, the structural refinement based on the intensity data collected at ambient- $T$ and 9.4(3) GPa, after the $P-T$ ramp, did not show any evidence of de-hydroxylation. However, we cannot entirely exclude that, even in the $P$ - $T$ range here investigated, but increasing the exposure time at the highest $T$, pargasite might experience (partial) de-hydroxylation.

In Fig. 8, all the $P-T$ data points collected on the pargasite crystal in this study are shown. In addition, Fig. 8 also shows the $P-T$ paths of the slab surface for arc segments in Tonga and central 
Peru, determined by Syracuse et al. (2010) on the basis of high-resolution finite-element models.

435 The stability field of pargasite observed in this study intersects the $P-T$ paths estimated for 436 subducting slabs when considering either a hot subduction (e.g., central Peru subduction) or a cold subduction pathway (e.g., Tonga subduction). The majority of phase equilibria studies involving pargasite have tested its stability within mafic or ultramafic assemblages and found it to be unstable above approximately $3 \mathrm{GPa}$ and $1273 \mathrm{~K}$. However, in these assemblages pargasite normally breaks down reacting with coexisting minerals, such as clinopyroxenes, whereas our experiments examined the stability of a pure pargasite crystal at $\mathrm{H}_{2} \mathrm{O}$-undersaturated conditions. As shown by Mandler and Grove (2016), significant variations in the stability of pargasite occur for assemblages containing differing proportions of $\mathrm{H}_{2} \mathrm{O}$ and with varying $\mathrm{Na} / \mathrm{K}$ ratio. To the best of our knowledge, the stability field of individual pargasite compositions has not been previously examined at the conditions employed here, but must extend to a wider $P-T$ range than those obtained in previous studies on multiple mineral assemblages. Overall, this study shows that pargasite has some potential to carry $\mathrm{H}_{2} \mathrm{O}$ (along with $\mathrm{Na}, \mathrm{K}$ and $\mathrm{Ca}$ ) into the transition zone and possibly beyond, within even hot subduction zones. This may have a significant influence on the $\mathrm{H}_{2} \mathrm{O}$ cycle of the mantle. Further experiments at simultaneous higher pressure and temperatures, as well as with prototypical subduction plate compositions, are needed.

\section{Acknowledgements}

Mario Tribaudino and Wilson Crichton are gratefully thanked for the useful and fruitful comments and suggestions. The Editor, Milan Rieder is acknowledged for handling the manuscript. PETRAIII synchrotron facility (Hamburg, Germany) is acknowledged for provision of beamtime at P02.2 beamline. ELETTRA (Trieste, Italy) synchrotron facility is acknowledged for beamtime at MCX beamline. J. Plaisier is thanked for the support during the experiment at ELETTRA. The authors acknowledge the University of Milano, the Doctoral School of Earth Science of the University of Milano, and the DCO (Deep Carbon Observatory) for supporting the research. 
463

464

465

466

467

468

469

470

471

472

473

474

475

476

477

478

479

480

481

482

483

484

485

486

487

488

489

490

491

492

493

494

495

496

497

498

499

500

501

502

503

504

505

506

\section{References}

Agilent Technologies (2011) Xcalibur CCD system, CrysAlisPro Software system, Version 1.171.35.XX. Agilent Technologies, Oxford.

Angel RJ, Hazen RM, Downs RT (2000) High-Temperature and High-Pressure Crystal Chemistry. Rev Mineral Geochem 41:35-60

Angel RJ, Bujak M, Zhao J, Gatta GD, Jacobsen SD (2007) Effective hydrostatic limits of pressure media for high-pressure crystallographic studies. J Appl Crystallogr 40:26-32.

Angel RJ, Alvaro M, Gonzalez-Platas J (2014) EosFit7c and a Fortran module (library) for equation of state calculations. Z Kristallogr 229:405-419.

Berman RG (1988) Internally-consistent thermodynamic data for minerals in the system $\mathrm{Na}_{2} \mathrm{O}-$ $\mathrm{K}_{2} \mathrm{O}-\mathrm{CaO}-\mathrm{MgO}-\mathrm{FeO}-\mathrm{Fe}_{2} \mathrm{O}_{3}-\mathrm{Al}_{2} \mathrm{O}_{3}-\mathrm{SiO}_{2}-\mathrm{TiO}_{2}-\mathrm{H}_{2} \mathrm{O}-\mathrm{CO}_{2}$. J Petrol 29:445-522

Boffa Ballaran T, Angel RJ, Carpenter MA (2000) High-pressure transformation behaviour of the cummingtonite-grunerite solid solution. Eur J Mineral 12:1195-1213

Bose K, GangulyJ (1994) Thermogravimetric study of the dehydration kinetics of talc Am Mineral 79: 692-699.

Cámara F, Oberti R, Iezzi G, Della Ventura G (2003) The $P 2_{1} / m \leftrightarrow C 2 / m$ phase transition in synthetic amphibole $\mathrm{Na}(\mathrm{NaMg}) \mathrm{Mg}_{5} \mathrm{Si}_{8} \mathrm{O} 22(\mathrm{OH})_{2}$ : thermodynamic and crystal-chemical evaluation. Phys Chem Mineral 30:570-581.

Cámara F, Oberti R, Casati N (2007) The $P 2_{1} / m \leftrightarrow C 2 / m$ phase transition in amphiboles: new data on synthetic $\mathrm{Na}(\mathrm{NaMg}) \mathrm{Mg}_{5} \mathrm{Si}_{8} \mathrm{O}_{22} \mathrm{~F}_{2}$ and the role of differential polyhedral expansion. $\mathrm{Z}$ Kristallogr 223:148-159.

Cameron M, Sueno S, Papike JJ, Prewitt CT (1983) High temperature crystal chemistry of K and Na fluor-richterites. Am Mineral 68:924-943.

Cawthorn RG (1975) The amphibole peridotite-metagabbro complex, Finero, northern Italy. J Geol $83: 437-454$

Coltorti M, Siena F (1984) Mantle tectonite and fractionate peridotite at Finero (Italian Western Alps), Neues Jahrb Mineral Abh 149:225-244

Comodi P, Mellini M, Ungaretti L, Zanazzi PF (1991) Compressibility and high pressure structure refinement of tremolite, pargasite, and glaucophane. Eur J Mineral 3:485-500 
Comodi P, Ballaran TB, Zanazzi PF, Capalbo C, Zanetti A, Nazzareni S (2010) The effect of oxocomponent on the high-pressure behavior of amphiboles. Am Mineral 95:1042-1051

Fei Y, Ricolleau A, Frank M, Mibe K, Shen G, Prakapenka V (2007). Toward an internally consistent pressure scale. Proc Natl Acad Sci USA 104:9182 - 9186.

Foley F, Tiepolo M, Vannucci R (2002) Growth of early continental crust controlled by melting of amphibolite in subduction zones. Nature 417:837-840

Forneris JF, Holloway JR (2003) Phase equilibria in subducting basaltic crust: implications for $\mathrm{H}_{2} \mathrm{O}$ release from the slab. Earth Planet Sci Lett 214:187-201

Fumagalli P, Poli S (2005) Experimentally determined phase relations in hydrous peridotites to 6.5 $\mathrm{GPa}$ and their consequences on the dynamics of subduction zones. J Petrol 46:555-578.

Gatta GD, McIntyre GJ, Oberti R, Hawthorne FC (2017) Order of ${ }^{[6]} \mathrm{Ti}^{4+}$ in a Ti-rich calcium amphibole from Kaersut, Greenland: a combined X-ray and neutron diffraction study. Phys Chem Minerals 44:83-94.

Gill J, Orogenic Andesites and Plate Tectonics (1981) Springer, New York, pp. 390.

Green DH, Wallace ME (1988) Mantle metasomatism by ephemeral carbonatite melt. Nature 336:459-462.

Hawthorne FC (1981) Amphiboles and Other Hydrous Pyriboles-Mineralogy. Rev Mineral 9A:1102.

Hawthorne FC, Oberti R, Sardone N (1996). Sodium at the A site in clinoamphiboles: the effects of composition on patterns of order. Can Mineral 34:577-593.

Hawthorne FC, Oberti R (2007) Amphiboles: Crystal chemistry. Rev Mineral Geochem 67:1-54.

Iezzi G, Tribaudino M, Della Ventura G, Nestola F, Bellatreccia F (2005a) High- $T$ phase transition of synthetic ${ }^{\mathrm{A}} \mathrm{Na}^{\mathrm{B}}(\mathrm{LiMg})^{\mathrm{C}} \mathrm{Mg}_{5} \mathrm{Si}_{8} \mathrm{O}_{22}(\mathrm{OH})_{2}$ amphibole: an X-ray synchrotron powder diffraction and FTIR spectroscopic study. Phys Chem Minerals 32:515-523

Iezzi G, Gatta GD, Kockelmann W, Della Ventura G, Rinaldi R, Schäfer W, Piccinini M, Gaillard F (2005b) Low- $T$ neutron powder-diffraction and synchrotron-radiation IR study of synthetic amphibole $\mathrm{Na}(\mathrm{NaMg}) \mathrm{Mg}_{5} \mathrm{Si}_{8} \mathrm{O}_{22}(\mathrm{OH})_{2}$. Am Mineral 90:695-700.

Iezzi G, Tribaudino M, Della Ventura G, Margiolaki I (2011) The high temperature $P 2{ }_{1} / m \rightarrow C 2 / m$ phase transitions in synthetic amphiboles along the richterite- $\left({ }^{\mathrm{B}} \mathrm{Mg}\right)$-richterite join. Am Mineral 96:353-363. 
Ionov DA and Hofmann AW (1995) Nb-Ta-rich mantle amphiboles and micas: Implications for subduction-related metasomatic trace element fractionations. Earth Planet Sci Lett 131:341-356.

Ionov DA, Bodinjer JL, Mukasa SB, Zanetti A (2002) Mechanisms and sources of mantle metasomatism: Major and trace element compositions of peridotite xenoliths from Spitsbergen in the context of numerical modelling. J Petrol 43:2219-2259.

Jenkins DM, Corona JC (2006) Molar volume and thermal expansion of glaucophane. Phys Chem Mineral 33:356-362.

Jenkins DM, Corona JC, Bassett WA, Mibe K, Wang ZW (2010) Compressibility of synthetic glaucophane. Phys Chem Miner: 37:219-226.

Klotz S, Chervin JC, Munsch P, Le Marchand G (2009) Hydrostatic limits of 11 pressure transmitting media. J Phys D Appl Phys. 42:075413 (7 pp.) DOI: 10.1088/0022-3727/42/7/075413.

Larson AC, Von Dreele RB (1994) GSAS Generalized structure analysis system. Los Alamos National Laboratory Report LAUR 86-748.

Le Bail A, Duroy H, Fourquet JL(1988) Ab-initio structure determination of LiSbWO 6 by X-ray powder diffraction. Mat Res Bull 23:447-452.

Mao HK, Xu J, Bell PM (1986) Calibration of the ruby pressure gauge to 800-kbar under quasihydrostatic conditions. J Geophys Res 91:4673-4676.

Mandler BE and Grovel TL (2016) Controls on the stability and composition of amphibole in the Earth's mantle. Contrib Mineral Petrol 171: 68-87.

Nestola F, Pasqual D, Welch MD, Oberti R (2012) The effects of composition upon the highpressure behaviour of amphiboles: compression of gedrite to $7 \mathrm{GPa}$ and a comparison with anthophyllite and proto-amphibole. Mineral Mag 76:987-995.

Niida K, Green DH (1999) Stability and chemical composition of pargasitic amphibole in MORB pyrolite under upper mantle conditions. Contr Mineral Petrol 135:18-40

Papike JJ, Ross M, Clark JR (1969) Crystal chemical characterization of clinoamphiboles based on five new structure refinements. Mineral Soc Am Spec Pap 2:117-136.

Petrŕíček V, Dušek M, Palatinus L (2014) Crystallographic Computing System JANA2006: General features. Z Kristallogr 229:345-352.

Poli S, Schmidt MW(1995) Water transport and release in subduction zones: Experimental constraints on basaltic and andesitic systems. J Geophys Res 100:22299-22314. 
Rebuffi L, Plaisier JR, Abdellatief M, Lausi A, Scardi P (2014) MCX: A synchrotron radiation beamline for X-ray diffraction line profile analysis. Z Anorg Allg Chem 640:3100-3106.

Reece JJ, Redfern SAT, Welch MD, Henderson CMB (2000) Mn-Mg disordering in cummingtonite: a high temperature neutron powder diffraction study. Mineral Mag 64:255-266.

Reece JJ, Redfern SAT, Welch MD, Henderson CMB, McCammon CA (2002) Temperaturedependent $\mathrm{Fe}^{2+}-\mathrm{Mn}^{2+}$ order-disorder behaviour in amphiboles. Phys Chem Mineral 29:562-570.

Rivalenti G, Garuti G and Rossi A (1975) The origin of the Ivrea-Verbano Basic Formation (Western Italian Alps), Whole rock chemistry. Boll Soc Geol Ital 94:1149-86.

Rivalenti G, Rossi A, Siena F, Sinigoi S (1984) The layered Series of the Ivrea-Verbano Igneous Complex, Western Alps, Italy. Tscher Miner Petrog 33:77-99.

Robinson P (1982) Phase relations of metamorphic amphiboles: natural occurrence and theory. Rev Mineral 9B: 1-3.

Rothkirch A, Gatta GD, Meyer M, Merkel S, Merlini M, Liermann H-P (2013) Single-crystal diffraction at the Extreme Conditions beamline P02.2: procedure for collecting and analyzing highpressure single-crystal data. J Synchrotron Rad 20:711-720.

Siena F, Coltorti M (1989), The petrogenesis of a hydrated mafic ultramafic complex and the role of amphibole fractionation at Finero(Italian Western Alps). Neues Jahrb Mineral Monatsh 6:255-274.

Schmidt MW, Poli S (1998) Experimentally based water budgets for dehydrating slabs and consequences for arc magma generation. Earth Planet Sci Lett 163:361-379.

Syracuse EM, van Keren PE, Abers GA (2010) The global range of subduction zone thermal models. Phys Earth Planet Inter 183:73-90.

Shen G., Liermann H.-P., Sinogeikin S., Yang W., Hong X., Yoo C-S., Cynn H. (2007) Distinct thermal behavior of $\mathrm{GeO}_{2}$ glass in tetrahedral, intermediate, and octahedral forms. Proc Nat Aca Sci 104:14576-14579.

Stern RJ (2002) Subduction zones. Rev Geophys 40:1012, DOI:10.1029/2001RG000108.

Sueno S, Cameron M, Papike JJ, Prewitt CT (1973) High temperature crystal chemistry of tremolite. Am Mineral 58:649-664.

Thompson P, Cox DE and Hastings JB (1987). Rietveld refinement of Debye-Scherrer synchrotron X-ray data of $\mathrm{Al}_{2} \mathrm{O}_{3}$. J Appl Cryst 20:79-83. 
Thompson EC, Campbell AJ Liu ZX (2016) In-situ infrared spectroscopic studies of hydroxyl in amphiboles at high pressure. Am Mineral 101:706-712.

Tribaudino M, Bruno M, Iezzi G, Della Ventura G, Margiolaki I (2008) The thermal behavior of richterite. Am Mineral 93:1659-1665.

Vannucci R, Piccardo GB, Rivalenti G, Zanetti A, Rampone E, Ottolini L, Oberti R, Mazzucchelli M, Bottazzi P. (1995) Origin of LrEE-depleted amphiboles in the subcontinental mantle. Geochim Cosmochim Acta 59:1763-1771.

Wallace ME, Green DH (1991) The effect of bulk rock composition on the stability of amphibole in the upper mantle: implications for solidus positions and mantle metasomatism. Mineral Petrol 44:119.

Welch MD, Knight KS (1999) A neutron powder diffraction study of cation ordering in hightemperature synthetic amphiboles. Eur J Mineral 11: 321-331.

Welch MD, Camara F, Della Ventura G, Iezzi G (2007) Non-ambient in situ studies of amphiboles. Rev Mineral Geochem 67:223-260.

Welch MD, Reece JJ, Redfern SAT (2008) Rapid intracrystalline exchange of divalent cations in amphiboles: a high-temperature neutron diffraction study of synthetic K-richterite ${ }^{\mathrm{A}} \mathrm{K}^{\mathrm{B}}(\mathrm{NaCa})$ ${ }^{\mathrm{C}}(\mathrm{Mg} 2.5 \mathrm{Ni} 2.5) \mathrm{Si}_{8} \mathrm{O}_{22}(\mathrm{OH})_{2}$. Mineral Mag 72:877-886.

Welch MD, Gatta GD, Rotiroti N (2011a) The high-pressure behavior of orthorhombic amphiboles. Am Mineral 96:623-630.

Welch MD, Cámara F, Oberti R (2011 b) Thermoelasticity and high- $T$ behaviour of anthophyllite. Phys Chem Miner 38: 321-334.

Yang H, Hazen RM, Prewitt CT, Finger LW, Lu R, Hemley RJ (1998) High-pressure single-crystal $\mathrm{X}$-ray diffraction and infrared spectroscopic studies of the $C 2 / m-P 2{ }_{1} / m$ phase transition in cummingtonite. Am Mineral 83:288-299.

Zema M, Welch MD, Oberti R (2012) High- $T$ behaviour of gedrite: thermoelasticity, cation ordering and dehydrogenation. Contrib Mineral Petrol 163: 923-937.

Zanazzi PF, Nestola F, Pasqual D (2010) Compressibility of protoamphibole: A high-pressure single-crystal diffraction study of protomangano-ferro-anthophyllite. Am Mineral 95:1758-1764.

Zhang L, Ahsbahs H, Kutoglu A, Hafner SS (1992) Compressibility of grunerite. Am Mineral 77:480-483. 
682

683

684

685

686

687

688

689

690

691

692

693

694

695

696

697

698

699

700

701

702

703

704

705

706

707

708

709

710

711

712

713

714

715

716

717

718

719

720

721

722

723

724

725

Figure. 1: Tetrahedral double chain and configuration of the pseudo-hexagonal ring. The relevant distances

O5-O5, O6-O6 and O7O7 are

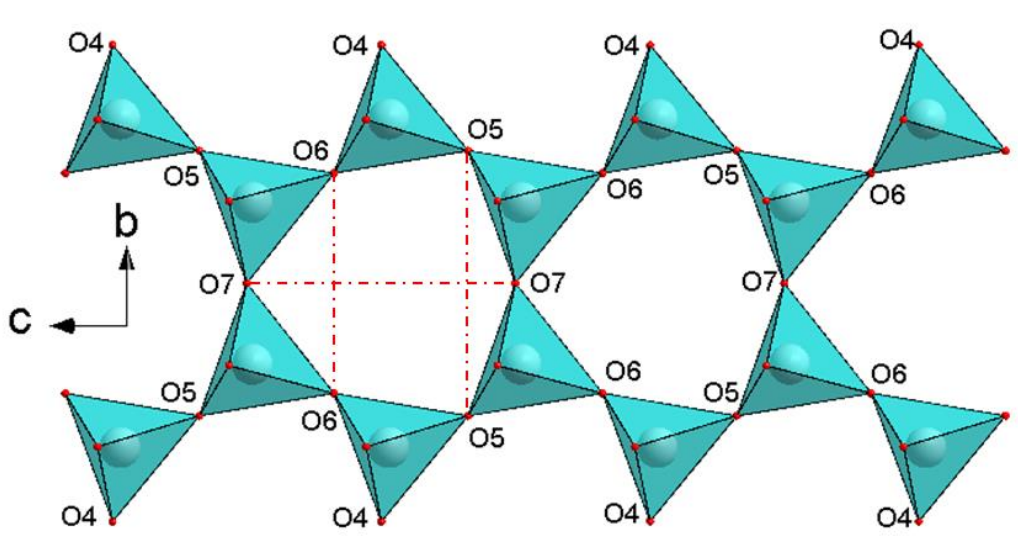
listed in Table 7.

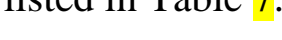


Figure 2: Crystal structure of pargasite at $P=1.99 \mathrm{GPa}$, viewed perpendicular to the $a b$ plane. It is 731 possible to note the bowing of the tetrahedral chain.

732

733

734

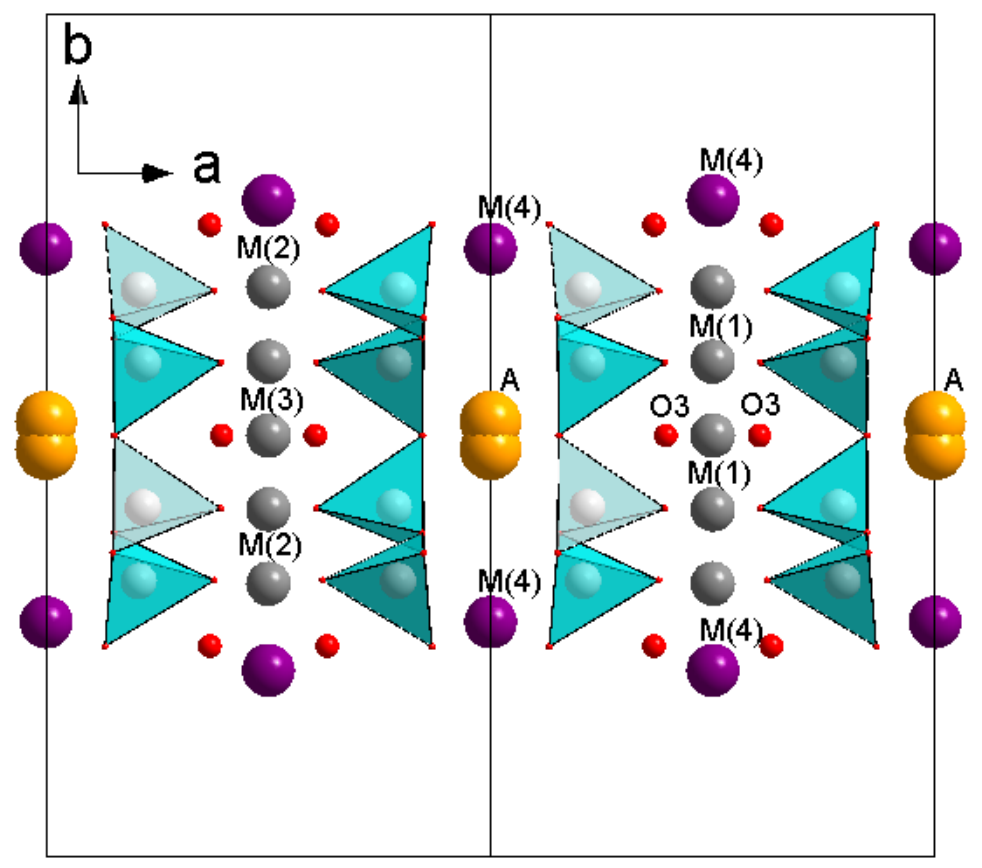


Figure 3 : High-temperature evolution of the (normalized) unit-cell volume and axial parameters of 761 pargasite; $V / V_{0}$ in black squares, $a / a_{0}$ red circles, $b / b_{0}$ blue triangles, $c / c_{0}$ cyan triangles.

762

763

764

765

766
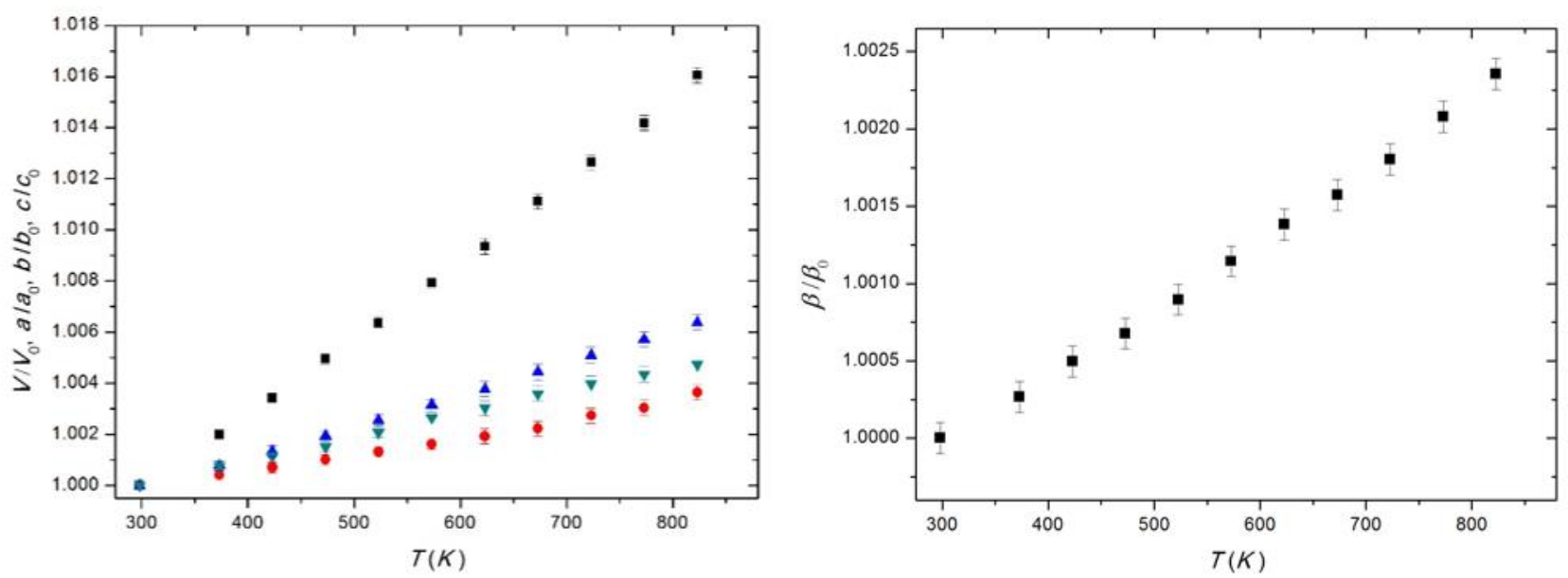

767

768

769

770

771

772

773

774

775 
776 Figure 4: High-pressure evolution of the (normalized) unit-cell volume and axial parameters of 777 pargasite. $V / V_{0}$ in black squares, $a / a_{0}$ red circles, $b / b_{0}$ blue triangles, $c / c_{0}$ cyan triangles.
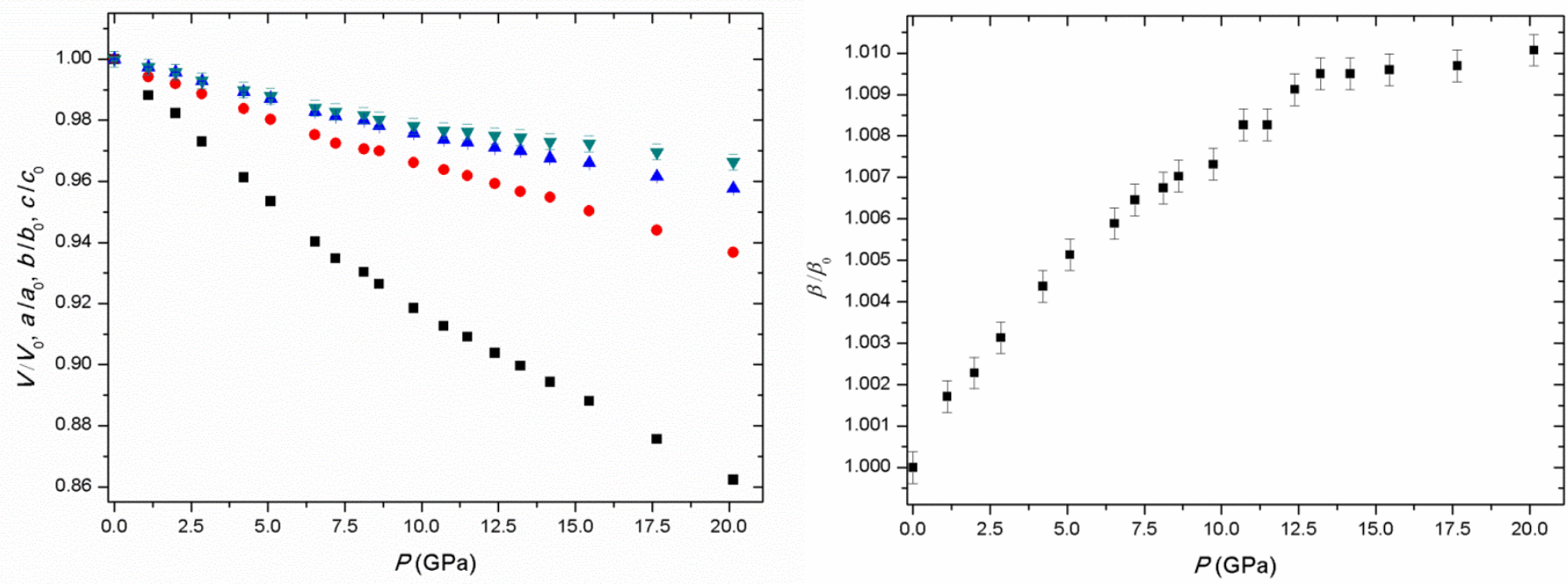


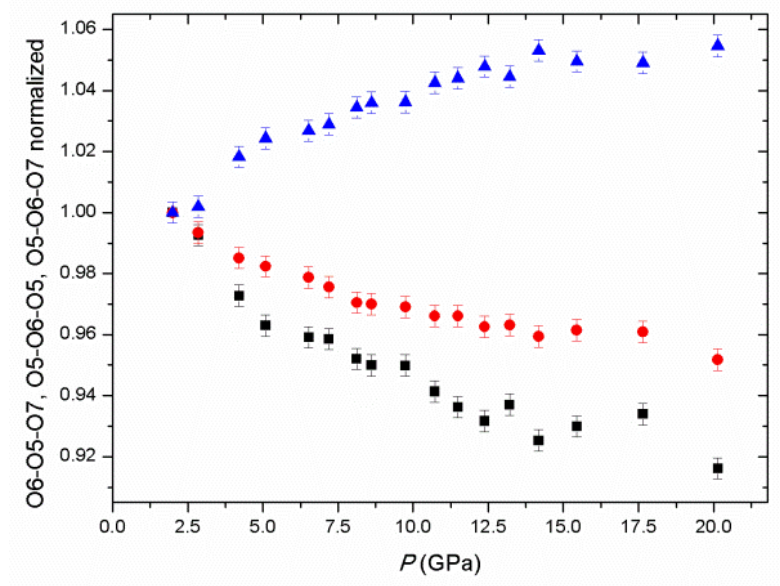

Figure 5. High-pressure evolution of principal $\mathrm{O}-\mathrm{O}-\mathrm{O}$ angles of the pseudo-hexagonal ring of tetrahedra; (left side) O6-O5-O7 (black squares), O5-O6-O5 (red circles),O5-O6-O7 (blue triangles); (right side) 05-O7-05 in black squares, O6-O7-O6 red circles.

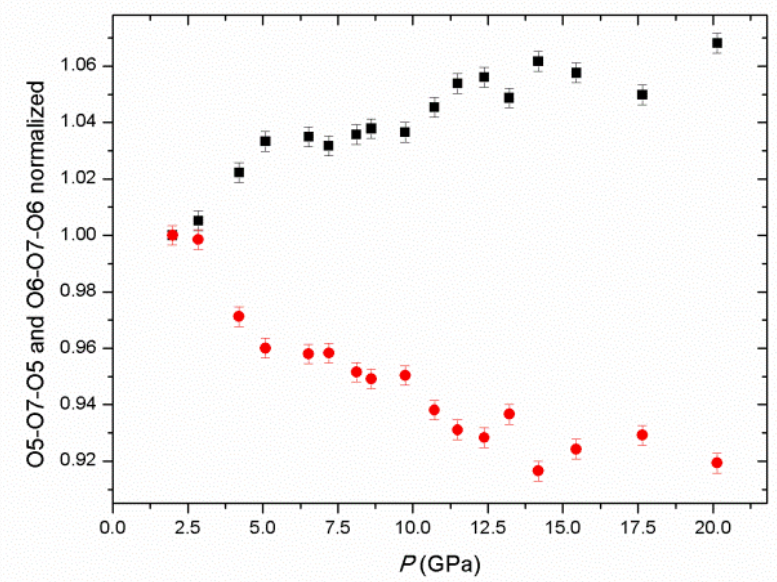

Figure 6. High-pressure evolution of principal diameters (normalized to their ambient $P$ values) of the pseudo-hexagonal ring of tetrahedra; O5-O5 (black squares), O6-O6 (red circles), O7-O7 (blue triangles).

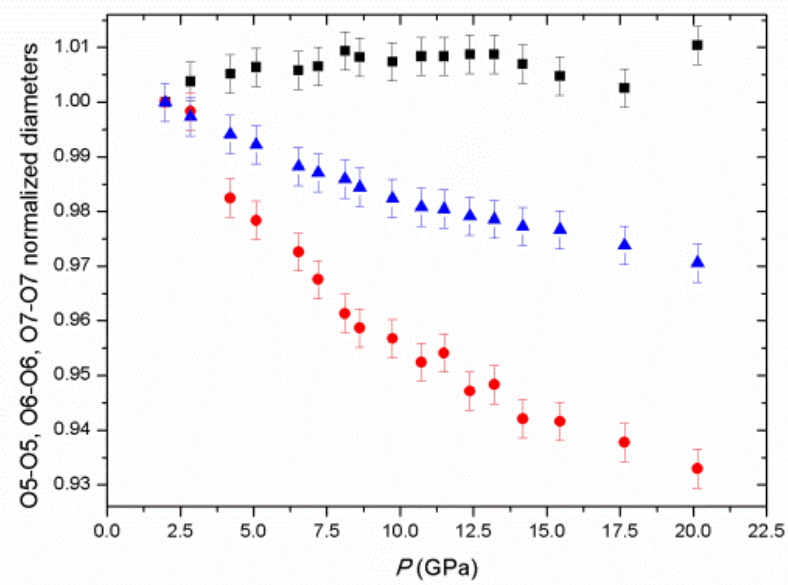


820 Figure 7. View of the bowing of the $\mathrm{TO}_{4}$ chain at (top left) $P=1.99 \mathrm{GPa}$ and (top right) at $P=$ $82120.14 \mathrm{GPa}$. (Bottom right) Evolution of the $\Delta x(\mathrm{O} 4-\mathrm{O} 7) \cdot a$.

822

823

824

825

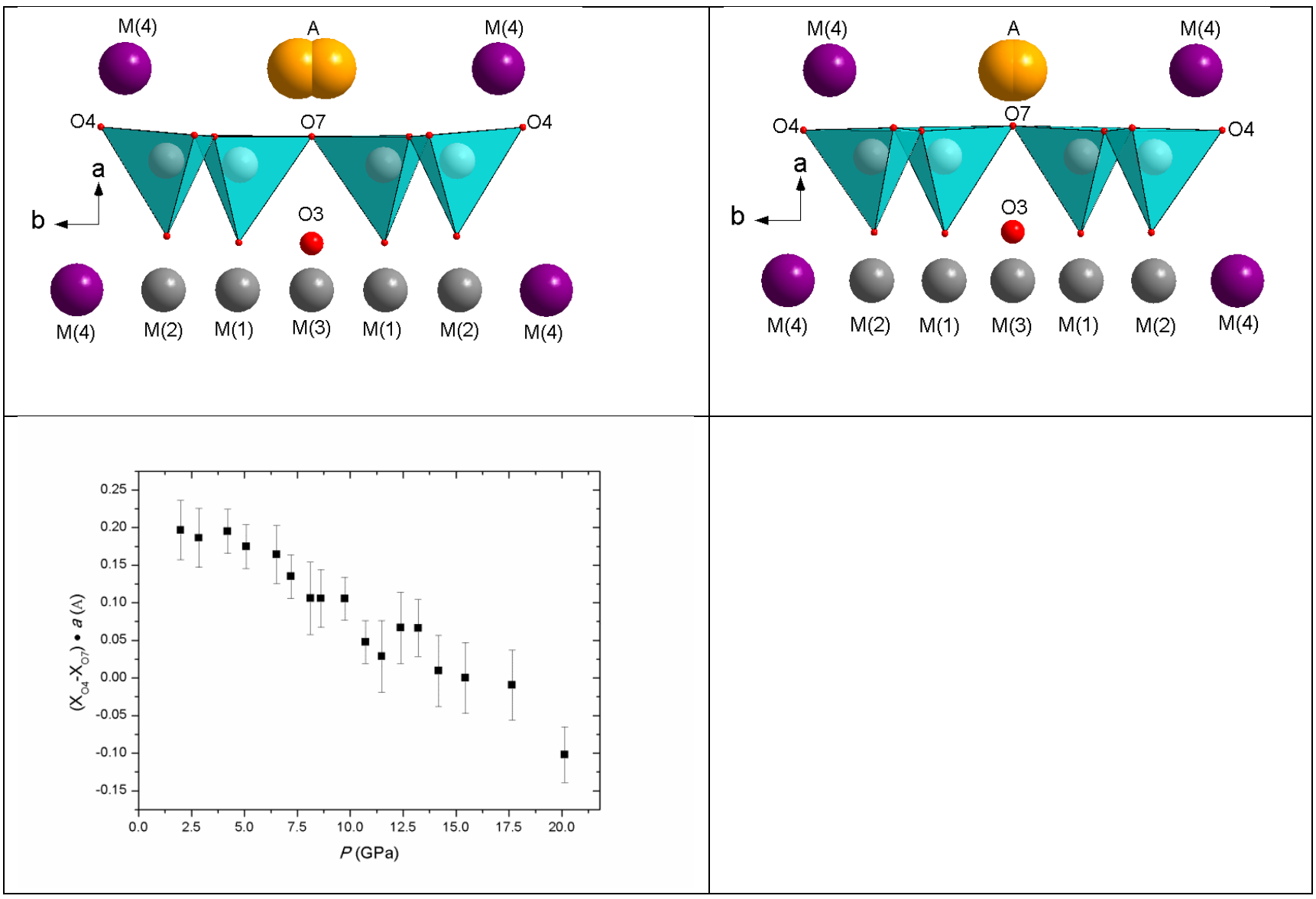

826

827

828

829

830 
831 Figure 8: $P-T$ diagram with all the experimental data points of this study (given in Tables 2-3-4). 832 The stability field of pargasite observed in this study intersects the $P$ - $T$ paths of the subduction slabs 833 either considering a hot subduction (e.g., central Peru subduction) or a cold subduction (e.g., Tonga 834 subduction) (Syracuse et al. 2010).

835

836

837

838

839

840

841

842

843

844

845

846

847

848

849

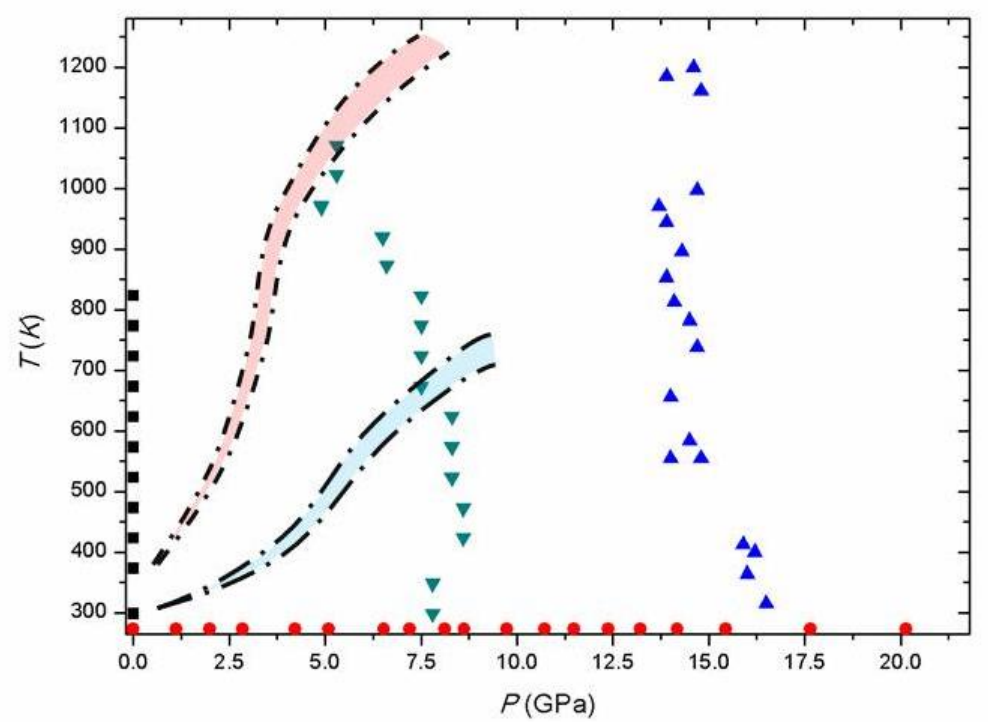

850

851

852

853

854

855

856

857

858

859

860

861 
862 Table 1: Compressional parameters of different amphiboles. Chemical formulae as given in the 863 quoted papers.

864

\begin{tabular}{|c|c|c|c|c|}
\hline Name & Chemical formula & $K_{\text {Рот0 }}$ & $K^{\prime}$ Рот0 & Reference \\
\hline Tremolite & $\mathrm{Ca}_{2}\left(\mathrm{Mg}_{4.95} \mathrm{Fe}^{+2}{ }_{0.05}\right) \mathrm{Si}_{8.00} \mathrm{O}_{22}(\mathrm{OH})_{2}$ & 85 & 4 & Comodi et al. (1991) \\
\hline Glaucophane & $\mathrm{Na}_{1.98} \mathrm{Li}_{0.02}\left(\mathrm{Mg}_{1.98} \mathrm{Fe}^{2+}{ }_{1.02} \mathrm{Fe}^{3+}{ }_{0.40} \mathrm{Al}_{1.60}\right) \mathrm{Si}_{8} \mathrm{O}_{22}(\mathrm{OH})_{2}$ & 96 & 4 & Comodi et al. (1991) \\
\hline Pargasite & $\begin{array}{c}\mathrm{K}_{0.02} \mathrm{Na}_{0.74} \mathrm{Ca}_{1.98} \mathrm{Fe}^{2+}{ }_{0.02} \\
\left(\mathrm{Mg}_{4.26} \mathrm{Fe}^{+2}{ }_{0.19} \mathrm{Cr}_{0.18} \mathrm{Tio}_{0.07} \mathrm{Al}_{0.30}\right)\left(\mathrm{Si}_{6.62} \mathrm{Al}_{1.38}\right) \mathrm{O}_{22}(\mathrm{OH})_{2}\end{array}$ & 97 & 4 & Comodi et al. (1991) \\
\hline $\begin{array}{l}\text { Protomangano- } \\
\text { ferro-anthophyllite }\end{array}$ & $\left(\mathrm{Mn}_{1.39} \mathrm{Fe}_{0.59}\right)\left(\mathrm{Fe}_{3.98} \mathrm{Mg}_{1.02}\right) \mathrm{Si}_{8} \mathrm{O}_{22}(\mathrm{OH})_{2}$ & $64(1)$ & $7.0(4)$ & Zanazzi et al. (2010) \\
\hline $\begin{array}{l}\text { Mg-rich } \\
\text { anthophyllite }\end{array}$ & $\begin{aligned} \mathrm{Na}_{0.04}\left(\mathrm{Mg}_{1.30} \mathrm{Mn}_{0.57} \mathrm{Ca}_{0.09} \mathrm{Na}_{0.04}\right)\left(\mathrm{Mg}_{4.96} \mathrm{Fe}_{0.02} \mathrm{Al}_{0.02}\right) & \left(\mathrm{Si}_{7.99} \mathrm{Al}_{0.01}\right) \mathrm{O}_{22}(\mathrm{OH})_{2}\end{aligned}$ & $66(2)$ & $11(1)$ & Welch et al. (2011) \\
\hline Grunerite & $\begin{array}{l}\left(\mathrm{Na}_{0.05} \mathrm{~K}_{0.01} \mathrm{Fe}^{2+}{ }_{5.33} \mathrm{Mg}_{1.46} \mathrm{Fe}^{3+}{ }_{0.14} \mathrm{Al}_{0.01}\right) \\
\quad\left(\mathrm{Si}_{7.92} \mathrm{Al}_{0.08}\right) \mathrm{O}_{22}\left(\mathrm{OH}_{1.92} \mathrm{~F}_{0.05} \mathrm{Cl}_{0.01}\right)\end{array}$ & $50(1)$ & $13(1)$ & Zhang et al. (1992) \\
\hline Kaersutite & $\begin{array}{c}{ }^{\mathrm{A}}\left(\mathrm{Ca}_{0.033} \mathrm{Na}_{0.682} \mathrm{~K}_{0.285}\right){ }^{\mathrm{M} 4}\left(\mathrm{Mg}_{0.21} \mathrm{Ca}_{1.79}\right) \\
\mathrm{M1-M2- \textrm {M } 3}\left(\mathrm{Al}_{0.428} \mathrm{Fe}^{3+}{ }_{1.273} \mathrm{Ti}_{0.585} \mathrm{Cr}_{0.004} \mathrm{Ni}_{0.004} \mathrm{Mg}_{2.648} \mathrm{Fe}^{2+}{ }_{0.047} \mathrm{Mn}_{0.013}\right) \\
{ }_{\mathrm{T}}\left(\mathrm{Si}_{5.972} \mathrm{Al}_{2.028}\right) \mathrm{O}_{22}\left(\mathrm{OH}_{1.949} \mathrm{~F}_{0.43} \mathrm{Cl}_{0.008}\right)\end{array}$ & $94(1)$ & $6.3(4)$ & Comodi et al. (2010) \\
\hline Gedrite & 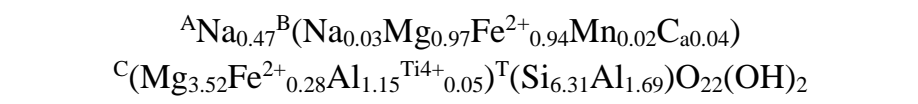 & $91.2(6)$ & $6.3(2)$ & Nestola et al. (2012) \\
\hline
\end{tabular}


865

866

867

868

Table 2: Unit-cell parameters of pargasite pertaining to the high-pressure experiment.

\begin{tabular}{ccccccr}
\hline & $P(\mathrm{GPa})$ & $V\left(\AA^{3}\right)$ & $a(\AA)$ & $b(\AA)$ & $c(\AA)$ & $\beta(869)$ \\
\hline$P 1$ & 0.0001 & $914.5(6)$ & $9.911(5)$ & $18.053(1)$ & $5.2971(7)$ & $105.23(7)$ \\
$P 2$ & $1.11(5)$ & $903.7(6)$ & $9.854(5)$ & $18.006(1)$ & $5.2831(7)$ & $105.41(2)$ \\
$P 3$ & $1.99(5)$ & $898.3(6)$ & $9.831(5)$ & $17.976(1)$ & $5.2742(7)$ & $105.47(2)$ \\
$P 4$ & $2.85(5)$ & $889.8(6)$ & $9.799(5)$ & $17.922(1)$ & $5.2596(7)$ & $105.56(2)$ \\
$P 5$ & $4.21(5)$ & $879.1(6)$ & $9.750(5)$ & $17.861(1)$ & $5.2434(7)$ & $105.69(2)$ \\
$P 6$ & $5.09(5)$ & $872.0(6)$ & $9.716(5)$ & $17.821(1)$ & $5.2328(7)$ & $105.77(2)$ \\
$P 7$ & $6.53(5)$ & $859.9(6)$ & $9.665(5)$ & $17.743(1)$ & $5.2121(7)$ & $105.85(2)$ \\
$P 8$ & $7.20(5)$ & $854.8(6)$ & $9.638(5)$ & $17.715(1)$ & $5.2059(7)$ & $105.91(2)$ \\
$P 9$ & $8.12(5)$ & $850.8(6)$ & $9.619(5)$ & $17.691(1)$ & $5.1996(7)$ & $105.94(2)$ \\
$P 10$ & $8.62(5)$ & $847.2(6)$ & $9.613(5)$ & $17.657(1)$ & $5.1919(7)$ & $105.9 \AA(2)$ \\
$P 11$ & $9.74(5)$ & $840.0(6)$ & $9.575(5)$ & $17.616(1)$ & $5.1808(7)$ & $106.06(2)$ \\
$P 12$ & $10.72(5)$ & $834.6(6)$ & $9.552(5)$ & $17.579(1)$ & $5.1730(7)$ & $106.18(21)$ \\
$P 13$ & $11.49(5)$ & $831.4(6)$ & $9.533(5)$ & $17.560(1)$ & $5.1708(7)$ & $106.18(2)$ \\
$P 14$ & $12.38(5)$ & $826.5(6)$ & $9.507(5)$ & $17.530(1)$ & $5.1640(7)$ & $106.19(23)$ \\
$P 15$ & $13.21(5)$ & $822.7(6)$ & $9.481(5)$ & $17.512(1)$ & $5.1611(7)$ & $106.23(84)$ \\
$P 16$ & $14.18(5)$ & $817.9(6)$ & $9.463(5)$ & $17.468(1)$ & $5.1535(7)$ & $106.23(85)$ \\
$P 17$ & $15.45(5)$ & $812.2(6)$ & $9.419(5)$ & $17.439(1)$ & $5.1506(7)$ & $106.248(86)$ \\
$P 18$ & $17.65(5)$ & $800.8(6)$ & $9.356(5)$ & $17.360(1)$ & $5.1359(7)$ & $106.25(87)$ \\
$P 19$ & $20.14(5)$ & $788.6(6)$ & $9.284(5)$ & $17.289(1)$ & $5.1189(7)$ & $106.29(28)$ \\
\hline
\end{tabular}

889

890

891

892

893

894

895

896

897

898

899

900

901

902

903

904

905

906

907

908 
909

910

911

912

913

\begin{tabular}{ccc|ccc}
\hline$P(\mathrm{GPa})$ & $T(\mathrm{~K})$ & $V\left(\AA^{3}\right)$ & $P(\mathrm{GPa})$ & $T(K)$ & $V\left(\AA^{3}\right)$ \\
\hline 7.8 & 298 & $854.0(5)$ & 16.5 & 315 & $804.9(4)$ \\
7.8 & 348 & $855.3(5)$ & 16.0 & 364 & $808.1(4)$ \\
8.6 & 424 & $849.7(5)$ & 16.2 & 400 & $807.8(4)$ \\
8.6 & 472 & $853.8(5)$ & 15.9 & 413 & $809.7(5)$ \\
8.3 & 523 & $855.2(5)$ & 14.8 & 555 & $821.3(5)$ \\
8.3 & 523 & $855.2(5)$ & 14.0 & 555 & $822.7(6)$ \\
8.3 & 573 & $856.9(5)$ & 14.5 & 584 & $820.6(5)$ \\
8.3 & 574 & $856.9(5)$ & 14.0 & 656 & $825.2(5)$ \\
8.3 & 624 & $858.3(5)$ & 14.7 & 738 & $823.3(4)$ \\
7.5 & 673 & $862.0(5)$ & 14.5 & 782 & $825.3(4)$ \\
7.5 & 724 & $866.7(5)$ & 14.1 & 813 & $827.8(10)$ \\
7.5 & 774 & $868.9(5)$ & 13.9 & 853 & $830.2(7)$ \\
7.5 & 823 & $870.8(5)$ & 14.3 & 896 & $828.7(5)$ \\
6.6 & 873 & $875.2(5)$ & 13.9 & 944 & $832.0(6)$ \\
6.5 & 919 & $878.8(5)$ & 13.7 & 971 & $833.9(7)$ \\
6.5 & 920 & $878.8(5)$ & 14.7 & 997 & $829.3(8)$ \\
4.9 & 971 & $893.9(5)$ & 14.7 & 997 & $828.9(7)$ \\
4.9 & 969 & $893.9(5)$ & 14.8 & 1161 & $832.3(8)$ \\
5.3 & 1023 & $889.5(5)$ & 13.9 & 1185 & $837.9(7)$ \\
5.3 & 1071 & $893.0(5)$ & 14.6 & 1199 & $834.2(9)$ \\
& & & 9.4 & 298 & $840(2)$ \\
\hline
\end{tabular}

Table 3: Unit-cell volume of pargasite pertaining to the $\mathrm{H} P-\mathrm{H} T$ experiments. Estimated average uncertainties: $\pm 0.5-0.8 \mathrm{GPa}$ in $P, \pm 15 \mathrm{~K}$ in $T$.

914

915

916

917

918

919

920

921

922

923

924

925

926

927

928

929

930 

933

\begin{tabular}{cccccc}
\hline$T(\mathrm{~K})$ & $V\left(\AA^{3}\right)$ & $a(\AA)$ & $b(\AA)$ & $c(\AA)$ & $\beta\left(^{\circ}\right)$ \\
\hline 298 & $909.1(1)$ & $9.8849(8)$ & $18.025(1)$ & $5.2864(5)$ & $104.91(1)$ \\
$373(1)$ & $910.9(1)$ & $9.8890(8)$ & $18.039(1)$ & $5.2895(5)$ & $104.94(1)$ \\
$423(1)$ & $912.2(1)$ & $9.8917(8)$ & $18.049(1)$ & $5.2919(5)$ & $104.96(1)$ \\
$473(1)$ & $913.6(1)$ & $9.8946(8)$ & $18.060(1)$ & $5.2945(5)$ & $104.98(1)$ \\
$523(1)$ & $914.9(1)$ & $9.8977(8)$ & $18.071(1)$ & $5.2968(5)$ & $105.00(2)$ \\
$573(1)$ & $916.3(1)$ & $9.9009(9)$ & $18.082(1)$ & $5.2995(5)$ & $105.03(2)$ \\
$623(1)$ & $917.6(2)$ & $9.9043(9)$ & $18.093(1)$ & $5.3016(2)$ & $105.05(2)$ \\
$673(1)$ & $919.2(2)$ & $9.9074(9)$ & $18.105(1)$ & $5.3045(6)$ & $105.07(2)$ \\
$723(1)$ & $920.6(2)$ & $9.9115(9)$ & $18.117(1)$ & $5.3067(6)$ & $105.10(2)$ \\
$773(1)$ & $922.0(2)$ & $9.9147(9)$ & $18.128(2)$ & $5.3092(6)$ & $105.13(2)$ \\
$823(1)$ & $923.7(2)$ & $9.9215(1)$ & $18.140(2)$ & $5.3113(7)$ & $105.16(2)$ \\
\hline
\end{tabular}

934

935

936

937

938

939

940

941

942

943

944

945

946

947

948

949

950

951

952

953

954

955

956

957

958

959

960

961

962

Table 4: Unit-cell parameters of pargasite pertaining to the high-temperature experiment.

(1) 
964 TABLE 5 IS DEPOSITED (pag. 42)

965

966 TABLE 6 IS DEPOSITED (pag. 44)

967

968

969 
970

971

Table 7: Relevant bond distances $(\AA)$ of the M(4) and A sites.

\begin{tabular}{cccccccc}
\hline$P(\mathrm{GPa})$ & $\mathrm{M}(4)-\mathrm{O} 2$ & $\mathrm{M}(4)-\mathrm{O} 4$ & $\mathrm{M}(4)-\mathrm{O} 5$ & $\mathrm{M}(4)-\mathrm{O} 6$ & $\mathrm{~A}-\mathrm{O} 5$ & $\mathrm{~A}-\mathrm{O} 6$ & $\mathrm{~A}-\mathrm{O} 7$ \\
\hline $1.99(5)$ & $2.411(5)$ & $2.303(10)$ & $2.640(8)$ & $2.588(3)$ & $2.803(4)$ & $2.834(6)$ & $2.418(10)$ \\
$2.85(5)$ & $2.367(4)$ & $2.303(10)$ & $2.587(7)$ & $2.598(4)$ & $2.796(4)$ & $2.837(6)$ & $2.405(10)$ \\
$4.21(5)$ & $2.372(4)$ & $2.302(10)$ & $2.574(7)$ & $2.614(4)$ & $2.854(4)$ & $2.829(6)$ & $2.377(10)$ \\
$5.09(5)$ & $2.362(4)$ & $2.292(10)$ & $2.544(7)$ & $2.603(4)$ & $2.863(4)$ & $2.803(6)$ & $2.344(10)$ \\
$6.53(5)$ & $2.363(4)$ & $2.293(10)$ & $2.524(7)$ & $2.605(4)$ & $2.871(4)$ & $2.799(6)$ & $2.335(10)$ \\
$7.20(5)$ & $2.353(4)$ & $2.282(10)$ & $2.509(6)$ & $2.595(4)$ & $2.847(4)$ & $2.764(6)$ & $2.325(10)$ \\
$8.12(5)$ & $2.335(4)$ & $2.281(10)$ & $2.509(6)$ & $2.605(4)$ & $2.877(4)$ & $2.768(6)$ & $2.292(10)$ \\
$8.62(5)$ & $2.327(4)$ & $2.278(9)$ & $2.500(6)$ & $2.596(4)$ & $2.871(4)$ & $2.750(6)$ & $2.298(10)$ \\
$9.74(5)$ & $2.331(4)$ & $2.277(9)$ & $2.490(6)$ & $2.589(4)$ & $2.861(4)$ & $2.740(6)$ & $2.299(10)$ \\
$10.72(5)$ & $2.324(4)$ & $2.271(9)$ & $2.473(6)$ & $2.588(4)$ & $2.893(4)$ & $2.740(6)$ & $2.247(10)$ \\
$11.49(5)$ & $2.345(4)$ & $2.255(9)$ & $2.454(6)$ & $2.588(4)$ & $2.867(4)$ & $2.726(6)$ & $2.219(10)$ \\
$12.38(5)$ & $2.309(4)$ & $2.239(9)$ & $2.443(6)$ & $2.585(4)$ & $2.899(4)$ & $2.726(6)$ & $2.223(10)$ \\
$13.21(5)$ & $2.317(4)$ & $2.239(9)$ & $2.443(6)$ & $2.575(4)$ & $2.867(4)$ & $2.709(6)$ & $2.239(10)$ \\
$14.18(5)$ & $2.333(4)$ & $2.266(9)$ & $2.425(6)$ & $2.586(4)$ & $2.964(4)$ & $2.788(6)$ & $2.188(10)$ \\
$15.45(5)$ & $2.323(4)$ & $2.260(9)$ & $2.422(6)$ & $2.567(4)$ & $2.973(4)$ & $2.792(6)$ & $2.185(10)$ \\
$17.65(5)$ & $2.289(4)$ & $2.253(9)$ & $2.418(6)$ & $2.543(4)$ & $2.871(4)$ & $2.700(6)$ & $2.194(10)$ \\
$20.14(5)$ & $2.262(4)$ & $2.241(9)$ & $2.365(6)$ & $2.551(4)$ & $2.933(4)$ & $2.728(6)$ & $2.118(10)$ \\
\hline
\end{tabular}

972

973

974

975

976

977

978

979

980

981

982

983

984

985

986

987

988

989

990

991

992

993

994

995 
Table 8: Principal diameters $(\AA)$ of the pseudo-hexagonal ring of tetrahedra with $P$ (see Fig. 1).

997

998

\begin{tabular}{cccc}
\hline$P(\mathrm{GPa})$ & $\mathrm{O} 5-\mathrm{O} 5$ & $\mathrm{O} 6-\mathrm{O} 6$ & $\mathrm{O} 7-\mathrm{O} 7$ \\
\hline $1.99(5)$ & $5.010(6)$ & $4.161(5)$ & $5.274(10)$ \\
$2.85(5)$ & $5.029(6)$ & $4.154(5)$ & $5.260(10)$ \\
$4.21(5)$ & $5.036(6)$ & $4.088(5)$ & $5.243(10)$ \\
$5.09(5)$ & $5.042(6)$ & $4.071(5)$ & $5.233(10)$ \\
$6.53(5)$ & $5.039(6)$ & $4.047(5)$ & $5.212(10)$ \\
$7.20(5)$ & $5.043(6)$ & $4.026(5)$ & $5.206(10)$ \\
$8.12(5)$ & $5.057(6)$ & $4.000(5)$ & $5.200(10)$ \\
$8.62(5)$ & $5.051(6)$ & $3.989(5)$ & $5.192(10)$ \\
$9.74(5)$ & $5.047(6)$ & $3.981(5)$ & $5.181(10)$ \\
$10.72(5)$ & $5.052(6)$ & $3.963(5)$ & $5.173(10)$ \\
$11.49(5)$ & $5.052(6)$ & $3.970(5)$ & $5.171(10)$ \\
$12.38(5)$ & $5.054(6)$ & $3.941(4)$ & $5.164(10)$ \\
$13.21(5)$ & $5.054(6)$ & $3.946(5)$ & $5.161(10)$ \\
$14.18(5)$ & $5.045(6)$ & $3.920(4)$ & $5.154(10)$ \\
$15.45(5)$ & $5.034(6)$ & $3.918(4)$ & $5.151(10)$ \\
$17.65(5)$ & $5.023(6)$ & $3.902(4)$ & $5.136(10)$ \\
$20.14(5)$ & $5.062(6)$ & $3.882(2)$ & $5.119(10)$ \\
\hline
\end{tabular}

999

1000

1001

1002

1003

1004

1005

1006

1007

1008

1009

1010

1011

1012

1013

1014

1015

1016

1017

1018

1019

1020

1021

1022 
1023

1024

1025

1026

\begin{tabular}{l|llll}
\hline & $V_{0}, l_{0}\left(\AA^{3}, \AA\right)$ & $K_{\mathrm{P} 0, \mathrm{~T} 0}(\mathrm{GPa})$ & $K_{\mathrm{P} 0, \mathrm{~T} 0}$ & $\beta_{\mathrm{P} 0, \mathrm{~T} 0}\left(\mathrm{GPa}^{-1}\right)$ \\
\hline$V^{*}$ & $915.2(8)$ & $95(2)$ & 4 (fixed) & $0.0121(2)$ \\
$V^{* *}$ & $907(1)$ & $111(2)$ & 4 (fixed) & $0.0090(2)$ \\
$a^{*}$ & $9.909(4)$ & $76(2)$ & 4 (fixed) & $0.0044(2)$ \\
$b^{*}$ & $18.066(7)$ & $111(4)$ & 4 (fixed) & $0.0030(1)$ \\
$c^{*}$ & $5.299(5)$ & $122(12)$ & 4 (fixed) & $0.0027(3)$ \\
\hline
\end{tabular}

* Elastic parameters referred to the $P$-range $0.0001-6.53 \mathrm{GPa}$

** Elastic parameters referred to the $P$-range $7.20-20.14 \mathrm{GPa}$
1027

1028

1029

1030

1031

1032

1033

1034

1035

\begin{tabular}{c|cccr}
\hline & $V$ & $a$ & $b$ & $c$ \\
\hline$V_{0}, l_{0}\left(\AA^{3}, \AA\right)$ & $909.1(2)$ & $9.8854(7)$ & $18.0245(8)$ & $5.2859(49) 37$ \\
$\alpha_{0}\left(\mathrm{~K}^{-1}\right)$ & $2.7(2) \times 10^{-5}$ & $0.47(6) \times 10^{-5}$ & $1.07(4) \times 10^{-5}$ & $0.97(7) \times 110038$ \\
$\alpha_{1}\left(\mathrm{~K}^{-2}\right)$ & $1.4(6) \times 10^{-9}$ & $0.8(2) \times 10^{-9}$ & $0.6(2) \times 10^{-9}$ & $-0.2(3) \times 103^{9} 9$ \\
\hline
\end{tabular}

Table 10: Refined thermal parameters of pargasite based on Berman's equation fit (see text for details).

1041

1042

1043

1044

1045

1046

1047

1048

1049

1050

1051

1052

1053

1054

1055

1056

1057 
1058 1059 1060

1061

1062

1063

1064

1065

1066

1067

1068

1069

1070

1071

1072

1073

1074

1075

1076

1077

1078

1079

1080

1081

1082

1083

1084

Table 11: O-O-O angles $\left({ }^{\circ}\right)$ of the pseudo-hexagonal ring of tetrahedra with $P$.

\begin{tabular}{cccccc}
\hline$P(\mathrm{GPa})$ & O6-O5-O7 & O5-O6-O5 & O5-O6-O7 & O5-O7-O5 & O6-O7-O6 \\
\hline $1.99(5)$ & $101.32(5)$ & $161.66(7)$ & $138.62(5)$ & $138.96(3)$ & $101.12(3)$ \\
$2.85(5)$ & $100.57(4)$ & $160.59(7)$ & $138.89(5)$ & $139.67(3)$ & $100.97(3)$ \\
$4.21(5)$ & $98.56(4)$ & $159.26(7)$ & $141.15(5)$ & $142.05(3)$ & $98.21(3)$ \\
$5.09(5)$ & $97.57(4)$ & $158.81(7)$ & $141.99(5)$ & $143.59(3)$ & $97.08(3)$ \\
$6.53(5)$ & $97.18(4)$ & $158.22(7)$ & $142.34(5)$ & $143.81(3)$ & $96.87(3)$ \\
$7.20(5)$ & $97.12(4)$ & $157.70(7)$ & $142.63(5)$ & $143.37(3)$ & $96.90(3)$ \\
$8.12(5)$ & $96.46(4)$ & $156.88(7)$ & $143.39(5)$ & $143.93(3)$ & $96.22(3)$ \\
$8.62(5)$ & $96.25(4)$ & $156.82(7)$ & $143.61(5)$ & $144.22(3)$ & $95.98(3)$ \\
$9.74(5)$ & $96.24(4)$ & $156.65(7)$ & $143.64(5)$ & $144.03(3)$ & $96.10(3)$ \\
$10.72(5)$ & $95.38(4)$ & $156.17(7)$ & $144.52(5)$ & $145.26(3)$ & $94.86(3)$ \\
$11.49(5)$ & $94.86(4)$ & $156.18(7)$ & $144.72(5)$ & $146.44(4)$ & $94.15(3)$ \\
$12.38(5)$ & $94.40(4)$ & $155.60(7)$ & $145.25(5)$ & $146.74(4)$ & $93.87(3)$ \\
$13.21(5)$ & $94.94(4)$ & $155.69(7)$ & $144.79(5)$ & $145.72(3)$ & $94.71(3)$ \\
$14.18(5)$ & $93.75(4)$ & $155.10(7)$ & $145.98(5)$ & $147.52(4)$ & $92.68(3)$ \\
$15.45(5)$ & $94.22(4)$ & $155.42(7)$ & $145.48(5)$ & $146.96(4)$ & $93.46(3)$ \\
$17.65(5)$ & $94.63(4)$ & $155.33(7)$ & $145.42(5)$ & $145.88(4)$ & $93.96(3)$ \\
$20.14(5)$ & $92.83(4)$ & $153.86(5)$ & $146.19(5)$ & $148.42(4)$ & $92.96(3)$ \\
\hline
\end{tabular}

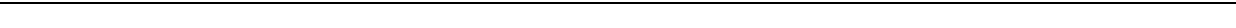


1085 1086 1087 1088 1089 1090 1091 1092 1093 1094 1095 1096 1097 1098 1099 1100 1101 1102 1103 1104 1105 1106 1107 1108 1109 1110 1111 1112 1113 1114 1115 1116 1117 1118 1119 1120 1121 1122 1123 1124 1125 1126 1127 1128

Table 12: Evolution of the parameter $\Delta x(\mathrm{O} 4-\mathrm{O} 7) \cdot a(\AA)$ with $P$ (see text for details).

\begin{tabular}{cc}
\hline$P(\mathrm{GPa})$ & $\Delta x(\mathrm{O} 4-\mathrm{O} 7) \cdot a(\AA)$ \\
\hline $1.99(5)$ & $0.20(4)$ \\
$2.85(5)$ & $0.19(4)$ \\
$4.21(5)$ & $0.20(3)$ \\
$5.09(5)$ & $0.17(3)$ \\
$6.53(5)$ & $0.16(4)$ \\
$7.20(5)$ & $0.13(3)$ \\
$8.12(5)$ & $0.11(5)$ \\
$8.62(5)$ & $0.11(4)$ \\
$9.74(5)$ & $0.11(3)$ \\
$10.72(5)$ & $0.05(3)$ \\
$11.49(5)$ & $0.03(5)$ \\
$12.38(5)$ & $0.07(5)$ \\
$13.21(5)$ & $0.07(4)$ \\
$14.18(5)$ & $0.01(5)$ \\
$15.45(5)$ & $0.00(5)$ \\
$17.65(5)$ & $-0.01(5)$ \\
$20.14(5)$ & $-0.10(4)$ \\
\hline
\end{tabular}




\begin{tabular}{cccccccc}
\hline$P(\mathrm{GPa})$ & $\mathrm{M}(1)$ & $\mathrm{M}(2)$ & $\mathrm{M}(3)$ & $\mathrm{M}(4)$ & $\mathrm{A}$ & $\mathrm{T}(1)$ & $\mathrm{T}(2)$ \\
\hline $1.99(5)$ & $11.45(9)$ & $11.37(9)$ & $10.95(9)$ & $25.5(1)$ & $44.2(3)$ & $2.38(2)$ & $2.22(2)$ \\
$2.85(5)$ & $11.48(9)$ & $11.25(9)$ & $11.24(9)$ & $24.9(1)$ & $43.8(3)$ & $2.35(2)$ & $2.26(2)$ \\
$4.21(5)$ & $11.11(9)$ & $11.02(9)$ & $10.62(9)$ & $24.9(1)$ & $43.1(3)$ & $2.37(2)$ & $2.23(2)$ \\
$5.09(5)$ & $11.04(9)$ & $10.95(9)$ & $10.64(9)$ & $24.5(1)$ & $41.9(3)$ & $2.36(2)$ & $2.24(2)$ \\
$6.53(5)$ & $11.1(1)$ & $10.99(9)$ & $10.7(1)$ & $24.4(1)$ & $41.6(3)$ & $2.31(2)$ & $2.18(2)$ \\
$7.20(5)$ & $10.9(1)$ & $10.8(1)$ & $10.5(1)$ & $24.0(1)$ & $40.7(3)$ & $2.34(2)$ & $2.21(2)$ \\
$8.12(5)$ & $10.8(1)$ & $10.5(1)$ & $10.3(1)$ & $24.0(1)$ & $40.2(3)$ & $2.38(2)$ & $2.22(2)$ \\
$8.62(5)$ & $10.8(1)$ & $10.5(1)$ & $10.6(1)$ & $23.7(1)$ & $39.8(3)$ & $2.35(2)$ & $2.24(2)$ \\
$9.74(5)$ & $10.8(1)$ & $10.6(1)$ & $10.6(1)$ & $23.7(1)$ & $39.7(3)$ & $2.31(2)$ & $2.19(2)$ \\
$10.72(5)$ & $10.8(1)$ & $10.6(1)$ & $10.5(1)$ & $23.4(1)$ & $38.4(3)$ & $2.33(2)$ & $2.19(2)$ \\
$11.49(5)$ & $10.9(1)$ & $10.6(1)$ & $10.5(1)$ & $23.2(1)$ & $37.9(3)$ & $2.34(2)$ & $2.17(2)$ \\
$12.38(5)$ & $10.6(1)$ & $10.3(1)$ & $10.4(1)$ & $22.7(1)$ & $37.6(3)$ & $2.34(2)$ & $2.23(2)$ \\
$13.21(5)$ & $10.6(1)$ & $10.4(1)$ & $10.4(1)$ & $22.8(1)$ & $37.7(3)$ & $2.30(2)$ & $2.19(2)$ \\
$14.18(5)$ & $10.5(1)$ & $10.6(1)$ & $10.1(1)$ & $23.1(2)$ & $37.0(4)$ & $2.32(2)$ & $2.14(2)$ \\
$15.45(5)$ & $10.6(1)$ & $10.4(1)$ & $10.1(1)$ & $22.8(1)$ & $36.4(4)$ & $2.30(2)$ & $2.16(2)$ \\
$17.65(5)$ & $10.4(1)$ & $10.2(1)$ & $10.1(1)$ & $22.3(2)$ & $35.9(4)$ & $2.29(2)$ & $2.16(2)$ \\
$20.14(5)$ & $10.3(1)$ & $10.2(1)$ & $10.0(1)$ & $21.7(2)$ & $35.2(4)$ & $2.24(3)$ & $2.16(3)$ \\
\hline
\end{tabular}

Table 13: Volumes of the coordination polyhedra $\left(\AA^{3}\right)$ at different pressures.
1133

1134

1135

1136

1137

1138

1139

1140

1141

1142

1143

1144

1145

1146

1147

1148

1149

1150

1151

1152

1153

1154

1155

(2)


1156 Table 14: Elastic parameters of the coordination polyhedra based on II-BM EoS fits.

1157

\begin{tabular}{l|ll}
\hline & $V_{0}\left(\AA^{3}\right)$ & $K_{0}(\mathrm{GPa})$ \\
\hline $\mathrm{T} 1$ & $2.41(2)$ & $310(70)$ \\
$\mathrm{T} 2$ & $2.31(6)$ & $302(57)$ \\
$\mathrm{M}(1)$ & $11.62(7)$ & $120(11)$ \\
$\mathrm{M}(2)$ & $11.5(1)$ & $107(14)$ \\
$\mathrm{M}(3)$ & $11.3(1)$ & $108(18)$ \\
$\mathrm{M}(4)$ & $26.0(1)$ & $79(5)$ \\
$\mathrm{A}$ & $46.9(3)$ & $38(2)$ \\
\hline
\end{tabular}

1158

1159

1160

1161

1162

1163

1164

1165

1166

1167

1168

1169

1170

1171

1172

1173

1174

1175

1176

1177

1178

1179

1180

1181

1182

1183

1184

1185

1186

1187

1188

1189

1190

1191

1192 
1193 Table 5 (deposited): Details pertaining to the structure refinements of pargasite at different 1194 pressures.

\begin{tabular}{|c|c|c|c|c|c|c|}
\hline & $\begin{array}{c}P 3 \\
1.99 \mathrm{GPa}\end{array}$ & $\begin{array}{c}P 4 \\
2.85 \mathrm{GPa}\end{array}$ & $\begin{array}{c}P 5 \\
4.21 \mathrm{GPa}\end{array}$ & $\begin{array}{c}P 6 \\
5.09 \mathrm{GPa}\end{array}$ & $\begin{array}{c}P 7 \\
6.53 \mathrm{GPa}\end{array}$ & $\begin{array}{c}P 8 \\
7.2 \mathrm{GPa}\end{array}$ \\
\hline $\min <h<\max$ & $-8 ;+7$ & $-8 ;+7$ & $-7 ;+8$ & $-8 ;+7$ & $-8 ;+7$ & $-8 ;+7$ \\
\hline $\min <k<\max$ & $-25 ;+27$ & $-25 ;+26$ & $-25 ;+26$ & $-25 ;+26$ & $-25 ;+26$ & $-25 ;+26$ \\
\hline $\min <l<\max$ & $-8 ;+7$ & $-7 ;+7$ & $-7 ;+7$ & $-7 ;+7$ & $-7 ;+7$ & $-7 ;+7$ \\
\hline Unique reflections & 540 & 547 & 559 & 542 & 542 & 550 \\
\hline $\begin{array}{c}\text { Observed reflections } I> \\
3 \sigma(I)\end{array}$ & 438 & 430 & 455 & 454 & 458 & 454 \\
\hline $\begin{array}{c}\text { Number of refined } \\
\text { parameters }\end{array}$ & 26 & 26 & 26 & 26 & 26 & 26 \\
\hline Number of restrains & 5 & 5 & 5 & 5 & 5 & 5 \\
\hline$R_{1}$ (obs) & 0.085 & 0.082 & 0.081 & 0.071 & 0.080 & 0.075 \\
\hline$R_{1}$ (all) & 0.101 & 0.103 & 0.109 & 0.080 & 0.093 & 0.088 \\
\hline$R_{\text {int }}(\mathrm{obs})$ & 0.058 & 0.050 & 0.036 & 0.030 & 0.030 & 0.029 \\
\hline$R_{\text {int }}$ (all) & 0.010 & 0.051 & 0.037 & 0.030 & 0.031 & 0.030 \\
\hline$w R_{1}$ (obs) & 0.102 & 0.101 & 0.091 & 0.083 & 0.107 & 0.085 \\
\hline$w R_{1}$ (all) & 0.104 & 0.104 & 0.099 & 0.084 & 0.109 & 0.088 \\
\hline Residuals $\left(e-/ \AA^{3}\right)$ & $\begin{array}{c}+0.25 ;- \\
0.36\end{array}$ & $\begin{array}{l}+0.30 ;- \\
0.35\end{array}$ & $\begin{array}{c}+0.58 ;- \\
0.44\end{array}$ & $\begin{array}{c}+0.32 ;- \\
0.49\end{array}$ & $\begin{array}{l}+0.37 ;- \\
0.47\end{array}$ & $\begin{array}{l}+0.33 ;- \\
0.46\end{array}$ \\
\hline
\end{tabular}

\begin{tabular}{|c|c|c|c|c|c|c|}
\hline & $\begin{array}{c}P 9 \\
8.12 \mathrm{GPa}\end{array}$ & $\begin{array}{c}P 10 \\
8.62 \mathrm{GPa}\end{array}$ & $\begin{array}{c}P 11 \\
9.74 \mathrm{GPa}\end{array}$ & $\begin{array}{c}P 12 \\
10.72 \\
\mathrm{GPa}\end{array}$ & $\begin{array}{c}P 13 \\
11.49 \\
\mathrm{GPa}\end{array}$ & $\begin{array}{c}P 14 \\
\mathrm{GPa}\end{array}$ \\
\hline min $<h<\max$ & $-7 ;+8$ & $-8 ;+7$ & $-8 ;+7$ & $-7 ;+8$ & $-7 ;+8$ & $-7 ;+8$ \\
\hline min $<k<\max$ & $-25 ;+26$ & $-25 ;+26$ & $-25 ;+26$ & $-25 ;+26$ & $-25 ;+26$ & $-25 ;+26$ \\
\hline min $<l<\max$ & $-7 ;+7$ & $-7 ;+7$ & $-7 ;+7$ & $-7 ;+7$ & $-7 ;+7$ & $-7 ;+7$ \\
\hline Unique reflections & 535 & 539 & 533 & 528 & 522 & 525 \\
\hline $\begin{array}{c}\text { Observed reflections } I> \\
3 \sigma(I)\end{array}$ & 441 & 444 & 442 & 436 & 424 & 421 \\
\hline $\begin{array}{c}\text { Number of refined } \\
\text { parameters }\end{array}$ & 26 & 26 & 26 & 26 & 26 & 26 \\
\hline Number of restrains & 5 & 5 & 5 & 5 & 5 & 5 \\
\hline$R_{1}(\mathrm{obs})$ & 0.082 & 0.074 & 0.080 & 0.080 & 0.084 & 0.072 \\
\hline$R_{1}($ all $)$ & 0.097 & 0.095 & 0.100 & 0.096 & 0.094 & 0.083 \\
\hline$R_{\text {int }}(\mathrm{obs})$ & 0.055 & 0.038 & 0.038 & 0.039 & 0.050 & 0.035 \\
\hline$R_{\text {int }}($ all $)$ & 0.055 & 0.038 & 0.38 & 0.039 & 0.051 & 0.036 \\
\hline$w R_{1}(\mathrm{obs})$ & 0.102 & 0.087 & 0.093 & 0.089 & 0.102 & 0.089 \\
\hline$w R_{1}($ all $)$ & 0.108 & 0.091 & 0.097 & 0.092 & 0.105 & 0.091 \\
\hline Residuals $\left(e-/ \AA^{3}\right)$ & $+0.38 ;-$ & $+0.35 ;-$ & $+0.33 ;-$ & $+0.30 ;-$ & $+0.28 ;-$ & $+0.33 ;-$ \\
0.40 & 0.43 & 0.42 & 0.40 & 0.40 & 0.38 \\
\hline
\end{tabular}




\begin{tabular}{|c|c|c|c|c|c|}
\hline & $\begin{array}{c}P 15 \\
13.21 \\
\mathrm{GPa}\end{array}$ & $\begin{array}{c}P 16 \\
14.18 \\
\mathrm{GPa}\end{array}$ & $\begin{array}{c}P 17 \\
15.45 \\
\mathrm{GPa}\end{array}$ & $\begin{array}{c}P 18 \\
17.65 \\
\mathrm{GPa}\end{array}$ & 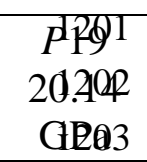 \\
\hline $\min <h<\max$ & $-7 ;+8$ & $-7 ;+8$ & $-7 ;+8$ & $-7 ;+8$ & $-81 ; z 04$ \\
\hline $\min <k<\max$ & $-24 ;+26$ & $-24 ;+26$ & $-24 ;+26$ & $-24 ;+26$ & $-24 ; ; z 85$ \\
\hline $\min <l<\max$ & $-7 ;+7$ & $-7 ;+7$ & $-7 ;+7$ & $-7 ;+7$ & $-7 ; ; \neq 06$ \\
\hline Unique reflections & 525 & 514 & 517 & 517 & 49297 \\
\hline $\begin{array}{c}\text { Observed reflections } I> \\
3 \sigma(I)\end{array}$ & 421 & 405 & 396 & 396 & $\begin{array}{r}318988 \\
1209\end{array}$ \\
\hline $\begin{array}{c}\text { Number of refined } \\
\text { parameters }\end{array}$ & 26 & 26 & 26 & 26 & 2610 \\
\hline Number of restrains & 5 & 5 & 5 & 5 & 15 \\
\hline$R_{\text {int }}$ (obs) & 0.077 & 0.080 & 0.083 & 0.086 & $0.113^{2}$ \\
\hline$R_{\text {int }}$ (all) & 0.098 & 0.091 & 0.098 & 0.111 & $0.145^{3}$ \\
\hline$R_{1}$ (obs) & 0.035 & 0.047 & 0.041 & 0.041 & 0.065 \\
\hline$R_{1}$ (all) & 0.036 & 0.048 & 0.042 & 0.042 & 0.066 \\
\hline$w R_{1}$ (obs) & 0.091 & 0.100 & 0.099 & 0.097 & 0.1216 \\
\hline$w R_{1}$ (all) & 0.095 & 0.101 & 0.103 & 0.102 & $0.1259^{7}$ \\
\hline Residuals $\left(e-/ \AA^{3}\right)$ & $\begin{array}{c}+0.42 ;- \\
0.44 \\
\end{array}$ & $\begin{array}{c}+0.25 ;- \\
0.27\end{array}$ & $\begin{array}{c}+0.42 ;- \\
0.36\end{array}$ & $\begin{array}{c}+0.52 ;- \\
0.32\end{array}$ & $\begin{array}{r}+0.31,- \\
01 \$ 99\end{array}$ \\
\hline
\end{tabular}


1243 Table 6 (deposited). Refined positional and displacement parameters of pargasite at different 1244 pressures. (*) fixed value; the s.o.f. are given as $\sum e$ - .

\begin{tabular}{|c|c|c|c|c|c|c|}
\hline Site & $P(\mathrm{GPa})$ & $\sum e-$ & $x$ & $y$ & $z$ & $U_{\text {iso }}\left(\AA^{2}\right)$ \\
\hline \multirow[t]{17}{*}{$\mathrm{T}(1)(\mathrm{Si})$} & $1.99(5)$ & 14 & $0.2825(7)$ & $0.0851(1)$ & $0.3059(6)$ & $0.007(5)$ \\
\hline & $2.85(5)$ & 14 & $0.2851(7)$ & $0.0851(1)$ & $0.3073(6)$ & $0.008(5)$ \\
\hline & $4.21(5)$ & 14 & $0.2847(6)$ & $0.0848(1)$ & $0.3073(5)$ & $0.008(4)$ \\
\hline & $5.095)$ & 14 & $0.2856(5)$ & $0.0848(1)$ & $0.3077(5)$ & $0.009(4)$ \\
\hline & $6.53(5)$ & 14 & $0.2875(7)$ & $0.0846(1)$ & $0.3089(6)$ & $0.009(5)$ \\
\hline & $7.20(5)$ & 14 & $0.2882(5)$ & $0.0847(1)$ & $0.3102(5)$ & $0.009(4)$ \\
\hline & $8.12(5)$ & 14 & $0.2878(9)$ & $0.0846(1)$ & $0.3097(8)$ & $0.010(7)$ \\
\hline & $8.62(5)$ & 14 & $0.2862(8)$ & $0.0845(1)$ & $0.3094(7)$ & $0.010(6)$ \\
\hline & $9.74(5)$ & 14 & $0.2873(6)$ & $0.0846(1)$ & $0.3099(6)$ & $0.009(4)$ \\
\hline & $10.72(5)$ & 14 & $0.2892(6)$ & $0.0845(1)$ & $0.3112(6)$ & $0.010(4)$ \\
\hline & $11.49(5)$ & 14 & $0.2894(10)$ & $0.0846(2)$ & $0.3103(9)$ & $0.011(7)$ \\
\hline & $12.38(5)$ & 14 & $0.2897(8)$ & $0.0845(1)$ & $0.3112(7)$ & $0.011(6)$ \\
\hline & $13.21(5)$ & 14 & $0.2903(7)$ & $0.0846(1)$ & $0.3118(6)$ & $0.010(4)$ \\
\hline & $14.18(5)$ & 14 & $0.2913(10)$ & $0.0843(2)$ & $0.3108(9)$ & $0.013(7)$ \\
\hline & $15.45(5)$ & 14 & $0.2924(1)$ & $0.0845(2)$ & $0.3109(9)$ & $0.013(7)$ \\
\hline & $17.65(5)$ & 14 & $0.2919(8)$ & $0.0847(1)$ & $0.3109(7)$ & $0.011(5)$ \\
\hline & $20.14(5)$ & 14 & $0.2952(9)$ & $0.0845(2)$ & $0.3131(9)$ & $0.013(6)$ \\
\hline \multirow[t]{17}{*}{$\mathrm{T}(2)(\mathrm{Si})$} & $1.99(5)$ & 14 & $0.2918(7)$ & $0.1726(1)$ & $0.8138(6)$ & $0.007(5)$ \\
\hline & $2.85(5)$ & 14 & $0.2915(7)$ & $0.1728(1)$ & $0.8131(6)$ & $0.008(5)$ \\
\hline & $4.21(5)$ & 14 & $0.2917(6)$ & $0.1727(1)$ & $0.8139(5)$ & $0.008(4)$ \\
\hline & 5.095) & 14 & $0.2919(5)$ & $0.1727(1)$ & $0.8145(5)$ & $0.009(4)$ \\
\hline & $6.53(5)$ & 14 & $0.2937(7)$ & $0.1729(1)$ & $0.8153(6)$ & $0.009(5)$ \\
\hline & $7.20(5)$ & 14 & $0.2931(5)$ & $0.1729(1)$ & $0.8162(5)$ & $0.009(4)$ \\
\hline & $8.12(5)$ & 14 & $0.2916(10)$ & $0.1729(1)$ & $0.8149(8)$ & $0.010(7)$ \\
\hline & $8.62(5)$ & 14 & $0.2923(8)$ & $0.1728(1)$ & $0.8156(7)$ & $0.010(6)$ \\
\hline & $9.74(5)$ & 14 & $0.2936(6)$ & $0.1727(1)$ & $0.8165(5)$ & $0.009(4)$ \\
\hline & $10.72(5)$ & 14 & $0.2934(6)$ & $0.1729(1)$ & $0.8168(6)$ & $0.010(4)$ \\
\hline & $11.49(5)$ & 14 & $0.2933(10)$ & $0.1732(2)$ & $0.8163(8)$ & $0.011(7)$ \\
\hline & $12.38(5)$ & 14 & $0.2926(9)$ & $0.1731(1)$ & $0.8163(7)$ & $0.011(6)$ \\
\hline & $13.21(5)$ & 14 & $0.2936(7)$ & $0.1731(1)$ & $0.8172(6)$ & $0.010(4)$ \\
\hline & $14.18(5)$ & 14 & $0.2957(10)$ & $0.1734(2)$ & $0.8175(9)$ & $0.013(7)$ \\
\hline & $15.45(5)$ & 14 & $0.2963(10)$ & $0.1735(2)$ & $0.8170(9)$ & $0.013(7)$ \\
\hline & $17.65(5)$ & 14 & $0.2949(8)$ & $0.1733(1)$ & $0.8171(7)$ & $0.011(5)$ \\
\hline & $20.14(5)$ & 14 & $0.2939(10)$ & $0.1734(2)$ & $0.8160(9)$ & $0.013(6)$ \\
\hline
\end{tabular}




\begin{tabular}{|c|c|c|c|c|c|c|}
\hline Site & $P(\mathrm{GPa})$ & $\sum e-$ & $x$ & $y$ & $z$ & $U_{\text {iso }}\left(\AA^{2}\right)$ \\
\hline \multirow[t]{17}{*}{$\mathrm{M}(1)(\mathrm{Mg})$} & $1.99(5)$ & 12 & 0 & $0.0877(2)$ & 0.5 & $0.006^{*}$ \\
\hline & $2.85(5)$ & 12 & 0 & $0.0876(2)$ & 0.5 & $0.006^{*}$ \\
\hline & $4.21(5)$ & 12 & 0 & $0.0873(2)$ & 0.5 & $0.006^{*}$ \\
\hline & $5.095)$ & 12 & 0 & $0.0871(1)$ & 0.5 & $0.006 *$ \\
\hline & $6.53(5)$ & 12 & 0 & $0.0870(2)$ & 0.5 & $0.006^{*}$ \\
\hline & $7.20(5)$ & 12 & 0 & $0.0865(2)$ & 0.5 & $0.006 *$ \\
\hline & $8.12(5)$ & 12 & 0 & $0.0864(2)$ & 0.5 & $0.006 *$ \\
\hline & $8.62(5)$ & 12 & 0 & $0.0862(2)$ & 0.5 & $0.006 *$ \\
\hline & $9.74(5)$ & 12 & 0 & $0.0863(2)$ & 0.5 & $0.006^{*}$ \\
\hline & $10.72(5)$ & 12 & 0 & $0.0860(2)$ & 0.5 & $0.006 *$ \\
\hline & $11.49(5)$ & 12 & 0 & $0.0855(2)$ & 0.5 & $0.006 *$ \\
\hline & $12.38(5)$ & 12 & 0 & $0.0854(2)$ & 0.5 & $0.006 *$ \\
\hline & $13.21(5)$ & 12 & 0 & $0.0855(2)$ & 0.5 & $0.006^{*}$ \\
\hline & $14.18(5)$ & 12 & 0 & $0.0849(3)$ & 0.5 & $0.006 *$ \\
\hline & $15.45(5)$ & 12 & 0 & $0.0848(3)$ & 0.5 & $0.006 *$ \\
\hline & $17.65(5)$ & 12 & 0 & $0.0848(2)$ & 0.5 & $0.006 *$ \\
\hline & $20.14(5)$ & 12 & 0 & $0.0841(3)$ & 0.5 & $0.006 *$ \\
\hline \multirow[t]{17}{*}{$\begin{array}{l}\mathrm{M}(2) \\
(\mathrm{Mg}+\mathrm{Cr})\end{array}$} & $1.99(5)$ & $13.6(7)$ & 0 & $0.175(8)$ & 0 & $0.006 *$ \\
\hline & $2.85(5)$ & $13.6(6)$ & 0 & $0.173(3)$ & 0 & $0.006 *$ \\
\hline & $4.21(5)$ & $13.8(4)$ & 0 & $0.174(9)$ & 0 & $0.006 *$ \\
\hline & $5.095)$ & $13.4(4)$ & 0 & $0.174(3)$ & 0 & $0.006 *$ \\
\hline & $6.53(5)$ & $13.7(10)$ & 0 & $0.172(4)$ & 0 & $0.006 *$ \\
\hline & $7.20(5)$ & $13.4(4)$ & 0 & $0.174(9)$ & 0 & $0.006 *$ \\
\hline & $8.12(5)$ & $13.6(7)$ & 0 & $0.179(3)$ & 0 & $0.006 *$ \\
\hline & $8.62(5)$ & $13.7(7)$ & 0 & $0.172(8)$ & 0 & $0.006 *$ \\
\hline & $9.74(5)$ & $13.7(4)$ & 0 & $0.173(9)$ & 0 & $0.006 *$ \\
\hline & $10.72(5)$ & $13.7(4)$ & 0 & $0.173(9)$ & 0 & $0.006 *$ \\
\hline & $11.49(5)$ & $14.0(7)$ & 0 & $0.168(1)$ & 0 & $0.006 *$ \\
\hline & $12.38(5)$ & $13.7(7)$ & 0 & $0.170(4)$ & 0 & $0.006 *$ \\
\hline & $13.21(5)$ & $13.4(4)$ & 0 & $0.173(1)$ & 0 & $0.006^{*}$ \\
\hline & $14.18(5)$ & $13.7(7)$ & 0 & $0.170(6)$ & 0 & $0.006 *$ \\
\hline & $15.45(5)$ & $13.6(7)$ & 0 & $0.171(1)$ & 0 & $0.006 *$ \\
\hline & $17.65(5)$ & $13.4(7)$ & 0 & $0.172 *$ & 0 & $0.006 *$ \\
\hline & $20.14(5)$ & $13.1(7)$ & 0 & $0.171(9)$ & 0 & $0.006 *$ \\
\hline
\end{tabular}




\begin{tabular}{|c|c|c|c|c|c|c|}
\hline Site & $P(\mathrm{GPa})$ & $\sum e-$ & $x$ & $y$ & $z$ & $U_{\text {iso }}\left(\AA^{2}\right)$ \\
\hline \multirow[t]{17}{*}{$\mathrm{M}(3)(\mathrm{Mg})$} & $1.99(5)$ & 12 & 0 & 0 & 0 & $0.006^{*}$ \\
\hline & $2.85(5)$ & 12 & 0 & 0 & 0 & $0.006^{*}$ \\
\hline & $4.21(5)$ & 12 & 0 & 0 & 0 & $0.006^{*}$ \\
\hline & $5.095)$ & 12 & 0 & 0 & 0 & $0.006^{*}$ \\
\hline & $6.53(5)$ & 12 & 0 & 0 & 0 & $0.006^{*}$ \\
\hline & $7.20(5)$ & 12 & 0 & 0 & 0 & $0.006^{*}$ \\
\hline & $8.12(5)$ & 12 & 0 & 0 & 0 & $0.006^{*}$ \\
\hline & $8.62(5)$ & 12 & 0 & 0 & 0 & $0.006^{*}$ \\
\hline & $9.74(5)$ & 12 & 0 & 0 & 0 & $0.006^{*}$ \\
\hline & $10.72(5)$ & 12 & 0 & 0 & 0 & $0.006^{*}$ \\
\hline & $11.49(5)$ & 12 & 0 & 0 & 0 & $0.006^{*}$ \\
\hline & $12.38(5)$ & 12 & 0 & 0 & 0 & $0.006^{*}$ \\
\hline & $13.21(5)$ & 12 & 0 & 0 & 0 & $0.006^{*}$ \\
\hline & $14.18(5)$ & 12 & 0 & 0 & 0 & $0.006^{*}$ \\
\hline & $15.45(5)$ & 12 & 0 & 0 & 0 & $0.006^{*}$ \\
\hline & $17.65(5)$ & 12 & 0 & 0 & 0 & $0.006^{*}$ \\
\hline & $20.14(5)$ & 12 & 0 & 0 & 0 & $0.006^{*}$ \\
\hline \multirow[t]{17}{*}{$\mathrm{M}(4)(\mathrm{Ca}+\mathrm{Na})$} & $1.99(5)$ & $19.2(12)$ & 0 & $0.2790(1)$ & 0.5 & $0.008(1)$ \\
\hline & $2.85(5)$ & $19.5(12)$ & 0 & $0.2780(1)$ & 0.5 & $0.010(1)$ \\
\hline & $4.21(5)$ & $19.0(9)$ & 0 & $0.2780(1)$ & 0.5 & $0.008(1)$ \\
\hline & $5.095)$ & $18.8(9)$ & 0 & $0.2779(1)$ & 0.5 & $0.008(1)$ \\
\hline & $6.53(5)$ & $19.0(9)$ & 0 & $0.2777(1)$ & 0.5 & $0.008(1)$ \\
\hline & $7.20(5)$ & $19.4(6)$ & 0 & $0.2775(1)$ & 0.5 & $0.009(1)$ \\
\hline & $8.12(5)$ & $18.7(12)$ & 0 & $0.2772(2)$ & 0.5 & $0.007(1)$ \\
\hline & $8.62(5)$ & $18.7(9)$ & 0 & $0.2771(1)$ & 0.5 & $0.007(1)$ \\
\hline & $9.74(5)$ & $19.1(9)$ & 0 & $0.2772(1)$ & 0.5 & $0.008(1)$ \\
\hline & $10.72(5)$ & 19.2(9) & 0 & $0.2768(1)$ & 0.5 & $0.008(1)$ \\
\hline & $11.49(5)$ & $18.5(12)$ & 0 & $0.2767(1)$ & 0.5 & $0.006(1)$ \\
\hline & $12.38(5)$ & $18.4(9)$ & 0 & $0.2765(1)$ & 0.5 & $0.007(1)$ \\
\hline & $13.21(5)$ & $18.8(9)$ & 0 & $0.2766(1)$ & 0.5 & $0.008(1)$ \\
\hline & $14.18(5)$ & $18.8(12)$ & 0 & $0.2765(2)$ & 0.5 & $0.007(1)$ \\
\hline & $15.45(5)$ & $18.8(12)$ & 0 & $0.2762(2)$ & 0.5 & $0.008(1)$ \\
\hline & $17.65(5)$ & 19.3(9) & 0 & $0.2761(1)$ & 0.5 & $0.009(1)$ \\
\hline & $20.14(5)$ & $19.4(12)$ & 0 & $0.2755(2)$ & 0.5 & $0.013(1)$ \\
\hline
\end{tabular}




\begin{tabular}{|l|l|l|l|l|l|l|}
\hline Site & $P(\mathrm{GPa})$ & $\sum e^{-}$ & $x$ & $y$ & $z$ & $U_{\text {iso }}\left(\AA^{2}\right)$ \\
\hline A (Na+K) & $1.99(5)$ & $6.1(4)$ & 0 & $0.484(1)$ & 0 & $0.074(6)$ \\
\hline & $2.85(5)$ & $6.1^{*}$ & 0 & $0.484(1)$ & 0 & $0.071(6)$ \\
\hline & $4.21(5)$ & $6.1^{*}$ & 0 & $0.487(1)$ & 0 & $0.079(6)$ \\
\hline & $5.095)$ & $6.1^{*}$ & 0 & $0.488(1)$ & 0 & $0.086(6)$ \\
\hline & $6.53(5)$ & $6.1^{*}$ & 0 & $0.489(2)$ & 0 & $0.077(7)$ \\
\hline & $7.20(5)$ & $6.1^{*}$ & 0 & $0.488(1)$ & 0 & $0.068(5)$ \\
\hline & $8.12(5)$ & $6.1^{*}$ & 0 & $0.489(2)$ & 0 & $0.080(10)$ \\
\hline & $8.62(5)$ & $6.1^{*}$ & 0 & $0.489(2)$ & 0 & $0.084(8)$ \\
\hline & $9.74(5)$ & $6.1^{*}$ & 0 & $0.488(1)$ & 0 & $0.071(6)$ \\
\hline & $10.72(5)$ & $6.1^{*}$ & 0 & $0.491(2)$ & 0 & $0.075(6)$ \\
\hline & $11.49(5)$ & $6.1^{*}$ & 0 & $0.490(2)$ & 0 & $0.084(10)$ \\
\hline & $12.38(5)$ & $6.1^{*}$ & 0 & $0.492(2)$ & 0 & $0.082(8)$ \\
\hline & $13.21(5)$ & $6.1^{*}$ & 0 & $0.490(1)$ & 0 & $0.068(6)$ \\
\hline & $14.18(5)$ & $6.1^{*}$ & 0 & $0.503(1)$ & 0 & $0.092(11)$ \\
\hline & $15.45(5)$ & $6.1^{*}$ & 0 & $0.499(2)$ & 0 & $0.094(12)$ \\
\hline & $17.65(5)$ & $6.1^{*}$ & 0 & $0.492(3)$ & 0 & $0.069(8)$ \\
\hline & $20.14(5)$ & $6.1^{*}$ & 0 & $0.495(6)$ & 0 & $0.075(12)$ \\
\hline & $1.99(5)$ & 8 & $0.107(2)$ & $0.086(3)$ & $0.220(2)$ & $0.012(1)$ \\
\hline & $2.85(5)$ & 8 & $0.109(2)$ & $0.0865(3)$ & $0.223(2)$ & $0.013(1)$ \\
\hline & $4.21(5)$ & 8 & $0.104(2)$ & $0.0860(3)$ & $0.218(1)$ & $0.012(1)$ \\
\hline & $5.095)$ & 8 & $0.106(1)$ & $0.0859(2)$ & $0.216(1)$ & $0.013(1)$ \\
\hline & $6.53(5)$ & 8 & $0.109(2)$ & $0.0855(3)$ & $0.218(2)$ & $0.012(1)$ \\
\hline & $7.20(5)$ & 8 & $0.107(1)$ & $0.0853(2)$ & $0.219(1)$ & $0.013(1)$ \\
\hline & $8.12(5)$ & 8 & $0.103(3)$ & $0.0854(4)$ & $0.217(2)$ & $0.015(1)$ \\
\hline & $8.62(5)$ & 8 & $0.105(2)$ & $0.0858(3)$ & $0.219(2)$ & $0.014(1)$ \\
\hline & $9.74(5)$ & 8 & $0.107(2)$ & $0.0856(3)$ & $0.220(1)$ & $0.012(1)$ \\
\hline & $10.72(5)$ & 8 & $0.108(2)$ & $0.0850(3)$ & $0.221(1)$ & $0.014(1)$ \\
\hline & $11.49(5)$ & 8 & $0.109(2)$ & $0.0845(4)$ & $0.222(2)$ & $0.015(1)$ \\
\hline & $12.38(5)$ & 8 & $0.107(2)$ & $0.0850(3)$ & $0.217(2)$ & $0.015(1)$ \\
\hline & $13.21(5)$ & 8 & $0.109(2)$ & $0.0849(3)$ & $0.221(2)$ & $0.014(1)$ \\
\hline & $14.18(5)$ & 8 & $0.108(2)$ & $0.0842(4)$ & $0.220(2)$ & $0.015(1)$ \\
\hline & $15.45(5)$ & 8 & $0.109(3)$ & $0.0844(4)$ & $0.221(2)$ & $0.014(1)$ \\
\hline & $17.65(5)$ & 8 & $0.108(2)$ & $0.0844(3)$ & $0.223(2)$ & $0.014(1)$ \\
\hline & $20.14(5)$ & 8 & $0.112(3)$ & $0.0833(4)$ & $0.221(2)$ & $0.016(1)$ \\
\hline & & & & & & \\
\hline
\end{tabular}




\begin{tabular}{|c|c|c|c|c|c|c|}
\hline Site & $P(\mathrm{GPa})$ & $\sum e-$ & $x$ & $y$ & $z$ & $U_{\text {iso }}\left(\AA^{2}\right)$ \\
\hline \multirow[t]{17}{*}{$\mathrm{O} 2$} & $1.99(5)$ & 8 & $0.122(2)$ & $0.1719(3)$ & $0.731(2)$ & $0.012(1)$ \\
\hline & $2.85(5)$ & 8 & $0.116(2)$ & $0.1722(3)$ & $0.728(2)$ & $0.013(1)$ \\
\hline & $4.21(5)$ & 8 & $0.117(2)$ & $0.1715(3)$ & $0.729(1)$ & $0.012(1)$ \\
\hline & $5.095)$ & 8 & $0.116(1)$ & $0.1712(2)$ & $0.727(1)$ & $0.013(1)$ \\
\hline & $6.53(5)$ & 8 & $0.119(2)$ & $0.1712(3)$ & $0.729(2)$ & $0.012(1)$ \\
\hline & $7.20(5)$ & 8 & $0.117(1)$ & $0.1708(2)$ & $0.729(1)$ & $0.013(1)$ \\
\hline & $8.12(5)$ & 8 & $0.114(3)$ & $0.1708(4)$ & $0.729(2)$ & $0.015(1)$ \\
\hline & $8.62(5)$ & 8 & $0.113(2)$ & $0.1705(3)$ & $0.728(2)$ & $0.014(1)$ \\
\hline & $9.74(5)$ & 8 & $0.115(2)$ & $0.1706(3)$ & $0.729(1)$ & $0.012(1)$ \\
\hline & $10.72(5)$ & 8 & $0.115(2)$ & $0.1702(3)$ & $0.728(1)$ & $0.014(1)$ \\
\hline & $11.49(5)$ & 8 & $0.118(2)$ & $0.1694(4)$ & $0.732(2)$ & $0.015(1)$ \\
\hline & $12.38(5)$ & 8 & $0.113(2)$ & $0.1698(3)$ & $0.728(2)$ & $0.015(1)$ \\
\hline & $13.21(5)$ & 8 & $0.115(2)$ & $0.1699(3)$ & $0.730(1)$ & $0.014(1)$ \\
\hline & $14.18(5)$ & 8 & $0.121(2)$ & $0.1698(4)$ & $0.731(2)$ & $0.015(1)$ \\
\hline & $15.45(5)$ & 8 & $0.120(3)$ & $0.1699(4)$ & $0.732(2)$ & $0.014(1)$ \\
\hline & $17.65(5)$ & 8 & $0.115(2)$ & $0.1698(3)$ & $0.730(2)$ & $0.014(1)$ \\
\hline & $20.14(5)$ & 8 & $0.115(3)$ & $0.1697(4)$ & $0.727(2)$ & $0.016(1)$ \\
\hline \multirow[t]{17}{*}{$\mathrm{O} 3$} & $1.99(5)$ & 8 & $0.105(3)$ & 0 & $0.720(2)$ & $0.012(1)$ \\
\hline & $2.85(5)$ & 8 & $0.111(2)$ & 0 & $0.724(2)$ & $0.013(1)$ \\
\hline & $4.21(5)$ & 8 & $0.109(2)$ & 0 & $0.721(2)$ & $0.012(1)$ \\
\hline & $5.095)$ & 8 & $0.108(2)$ & 0 & $0.717(2)$ & $0.013(1)$ \\
\hline & $6.53(5)$ & 8 & $0.110(2)$ & 0 & $0.718(2)$ & $0.012(1)$ \\
\hline & $7.20(5)$ & 8 & $0.110(2)$ & 0 & $0.720(2)$ & $0.013(1)$ \\
\hline & $8.12(5)$ & 8 & $0.114(3)$ & 0 & $0.725(3)$ & $0.015(1)$ \\
\hline & $8.62(5)$ & 8 & $0.117(3)$ & 0 & $0.725(2)$ & $0.014(1)$ \\
\hline & $9.74(5)$ & 8 & $0.116(2)$ & 0 & $0.723(2)$ & $0.012(1)$ \\
\hline & $10.72(5)$ & 8 & $0.116(2)$ & 0 & $0.724(2)$ & \begin{tabular}{|l|}
$0.014(1)$ \\
\end{tabular} \\
\hline & $11.49(5)$ & 8 & $0.121(3)$ & 0 & $0.730(3)$ & $0.015(1)$ \\
\hline & $12.38(5)$ & 8 & $0.118(3)$ & 0 & $0.719(2)$ & $0.015(1)$ \\
\hline & $13.21(5)$ & 8 & $0.118(2)$ & 0 & $0.722(2)$ & $0.014(1)$ \\
\hline & $14.18(5)$ & 8 & $0.111(3)$ & 0 & $0.719(3)$ & \begin{tabular}{|l|}
$0.015(1)$ \\
\end{tabular} \\
\hline & $15.45(5)$ & 8 & $0.115(3)$ & 0 & $0.723(3)$ & $0.014(1)$ \\
\hline & $17.65(5)$ & 8 & $0.120(3)$ & 0 & $0.727(2)$ & $0.014(1)$ \\
\hline & $20.14(5)$ & 8 & $0.117(3)$ & 0 & $0.721(3)$ & $0.016(1)$ \\
\hline
\end{tabular}




\begin{tabular}{|c|c|c|c|c|c|c|}
\hline Site & $P(\mathrm{GPa})$ & $\sum e-$ & $x$ & $y$ & $z$ & $U_{\text {iso }}\left(\AA^{2}\right)$ \\
\hline \multirow[t]{17}{*}{$\mathrm{O} 4$} & $1.99(5)$ & 8 & $0.368(2)$ & $0.2503(4)$ & $0.787(1)$ & $0.012(1)$ \\
\hline & $2.85(5)$ & 8 & $0.366(2)$ & $0.2500(3)$ & $0.786(1)$ & $0.013(1)$ \\
\hline & $4.21(5)$ & 8 & $0.365(1)$ & $0.2513(3)$ & $0.784(1)$ & $0.012(1)$ \\
\hline & 5.09 5) & 8 & $0.365(1)$ & $0.2517(2)$ & $0.784(1)$ & $0.013(1)$ \\
\hline & $6.53(5)$ & 8 & $0.364(2)$ & $0.2523(3)$ & $0.783(1)$ & $0.012(1)$ \\
\hline & $7.20(5)$ & 8 & $0.364(1)$ & $0.2524(2)$ & $0.783(1)$ & $0.013(1)$ \\
\hline & $8.12(5)$ & 8 & $0.364(2)$ & $0.2527(4)$ & $0.782(2)$ & $0.015(1)$ \\
\hline & $8.62(5)$ & 8 & $0.363(2)$ & $0.2528(4)$ & $0.780(1)$ & $0.014(1)$ \\
\hline & $9.74(5)$ & 8 & $0.362(1)$ & $0.2528(3)$ & $0.781(1)$ & $0.012(1)$ \\
\hline & $10.72(5)$ & 8 & $0.362(1)$ & $0.2532(3)$ & $0.779(1)$ & $0.014(1)$ \\
\hline & $11.49(5)$ & 8 & $0.363(2)$ & $0.2538(4)$ & $0.777(2)$ & $0.015(1)$ \\
\hline & $12.38(5)$ & 8 & $0.364(2)$ & $0.2539(4)$ & $0.776(2)$ & $0.015(1)$ \\
\hline & $13.21(5)$ & 8 & $0.364(2)$ & $0.2539(4)$ & $0.777(2)$ & $0.014(1)$ \\
\hline & $14.18(5)$ & 8 & $0.358(2)$ & $0.2552(4)$ & $0.773(2)$ & $0.015(1)$ \\
\hline & $15.45(5)$ & 8 & $0.359(2)$ & $0.2557(4)$ & $0.774(2)$ & $0.014(1)$ \\
\hline & $17.65(5)$ & 8 & $0.358(2)$ & $0.2550(4)$ & $0.774(2)$ & $0.014(1)$ \\
\hline & $20.14(5)$ & 8 & $0.358(2)$ & $0.2566(5)$ & $0.772(2)$ & $0.016(1)$ \\
\hline \multirow[t]{17}{*}{ O5 } & $1.99(5)$ & 8 & $0.350(1)$ & $0.1394(3)$ & $0.110(1)$ & $0.012(1)$ \\
\hline & $2.85(5)$ & 8 & $0.356(2)$ & $0.1403(3)$ & $0.116(2)$ & $0.013(1)$ \\
\hline & $4.21(5)$ & 8 & $0.356(2)$ & $0.1401(3)$ & $0.117(1)$ & $0.012(1)$ \\
\hline & 5.095) & 8 & $0.355(1)$ & $0.1414(2)$ & $0.121(1)$ & $0.013(1)$ \\
\hline & $6.53(5)$ & 8 & $0.354(2)$ & $0.1420(3)$ & $0.122(1)$ & $0.012(1)$ \\
\hline & $7.20(5)$ & 8 & $0.357(1)$ & $0.1423(2)$ & $0.123(1)$ & $0.013(1)$ \\
\hline & $8.12(5)$ & 8 & $0.355(2)$ & $0.1429(4)$ & $0.122(2)$ & $0.015(1)$ \\
\hline & $8.62(5)$ & 8 & $0.356(2)$ & $0.1430(3)$ & $0.123(2)$ & $0.014(1)$ \\
\hline & $9.74(5)$ & 8 & $0.356(2)$ & $0.1432(3)$ & $0.123(1)$ & $0.012(1)$ \\
\hline & $10.72(5)$ & 8 & $0.357(2)$ & $0.1437(3)$ & $0.125(1)$ & $0.014(1)$ \\
\hline & $11.49(5)$ & 8 & $0.359(2)$ & $0.1439(4)$ & $0.127(2)$ & $0.015(1)$ \\
\hline & $12.38(5)$ & 8 & $0.359(2)$ & $0.1441(3)$ & $0.129(2)$ & $0.015(1)$ \\
\hline & $13.21(5)$ & 8 & $0.359(2)$ & $0.1443(3)$ & $0.127(2)$ & $0.014(1)$ \\
\hline & $14.18(5)$ & 8 & $0.362(2)$ & $0.1444(4)$ & $0.129(2)$ & $0.015(1)$ \\
\hline & $15.45(5)$ & 8 & $0.362(2)$ & $0.1443(4)$ & $0.130(2)$ & $0.014(1)$ \\
\hline & $17.65(5)$ & 8 & $0.361(2)$ & $0.1447(3)$ & $0.127(2)$ & $0.014(1)$ \\
\hline & $20.14(5)$ & 8 & $0.363(2)$ & $0.1464(5)$ & $0.135(2)$ & $0.016(1)$ \\
\hline
\end{tabular}




\begin{tabular}{|c|c|c|c|c|c|c|}
\hline Site & $P(\mathrm{GPa})$ & $\sum e-$ & $x$ & $y$ & $z$ & $U_{\text {iso }}\left(\AA^{2}\right)$ \\
\hline \multirow[t]{17}{*}{ O6 } & $1.99(5)$ & 8 & $0.346(2)$ & $0.1157(3)$ & $0.611(2)$ & $0.012(1)$ \\
\hline & $2.85(5)$ & 8 & $0.345(2)$ & $0.1158(3)$ & $0.612(2)$ & $0.013(1)$ \\
\hline & $4.21(5)$ & 8 & $0.345(1)$ & $0.1144(3)$ & $0.615(1)$ & $0.012(1)$ \\
\hline & $5.095)$ & 8 & $0.348(1)$ & $0.1142(2)$ & $0.619(1)$ & $0.013(1)$ \\
\hline & $6.53(5)$ & 8 & $0.347(2)$ & $0.1140(3)$ & $0.620(1)$ & $0.012(1)$ \\
\hline & $7.20(5)$ & 8 & $0.349(1)$ & $0.1136(2)$ & $0.622(1)$ & $0.013(1)$ \\
\hline & $8.12(5)$ & 8 & $0.349(2)$ & $0.1130(4)$ & $0.622(2)$ & $0.015(1)$ \\
\hline & $8.62(5)$ & 8 & $0.351(2)$ & $0.1129(3)$ & $0.624(2)$ & $0.014(1)$ \\
\hline & $9.74(5)$ & 8 & $0.351(2)$ & $0.1129(3)$ & $0.624(1)$ & $0.012(1)$ \\
\hline & $10.72(5)$ & 8 & $0.353(1)$ & $0.1126(3)$ & $0.627(1)$ & $0.014(1)$ \\
\hline & $11.49(5)$ & 8 & $0.351(2)$ & $0.1131(4)$ & $0.627(2)$ & $0.015(1)$ \\
\hline & $12.38(5)$ & 8 & $0.354(2)$ & $0.1124(4)$ & $0.629(2)$ & $0.015(1)$ \\
\hline & $13.21(5)$ & 8 & $0.354(2)$ & $0.1126(4)$ & $0.628(2)$ & $0.014(1)$ \\
\hline & $14.18(5)$ & 8 & $0.353(2)$ & $0.1121(4)$ & $0.629(2)$ & $0.015(1)$ \\
\hline & $15.45(5)$ & 8 & $0.355(2)$ & $0.1123(4)$ & $0.629(2)$ & $0.014(1)$ \\
\hline & $17.65(5)$ & 8 & $0.357(2)$ & $0.1124(4)$ & $0.630(2)$ & $0.014(1)$ \\
\hline & $20.14(5)$ & 8 & $0.355(2)$ & $0.1124(5)$ & $0.629(2)$ & $0.016(1)$ \\
\hline \multirow[t]{17}{*}{$\mathrm{O} 7$} & $1.99(5)$ & 8 & $0.348(2)$ & 0 & $0.286(2)$ & $0.012(1)$ \\
\hline & $2.85(5)$ & 8 & $0.347(2)$ & 0 & $0.286(2)$ & $0.013(1)$ \\
\hline & $4.21(5)$ & 8 & $0.345(2)$ & 0 & $0.277(2)$ & $0.012(1)$ \\
\hline & 5.09 5) & 8 & $0.347(2)$ & 0 & $0.275(2)$ & $0.013(1)$ \\
\hline & $6.53(5)$ & 8 & $0.347(2)$ & 0 & $0.276(2)$ & $0.012(1)$ \\
\hline & $7.20(5)$ & 8 & $0.350(2)$ & 0 & $0.279(2)$ & $0.013(1)$ \\
\hline & $8.12(5)$ & 8 & $0.353(3)$ & 0 & $0.279(3)$ & $0.015(1)$ \\
\hline & $8.62(5)$ & 8 & $0.352(2)$ & 0 & $0.278(2)$ & $0.014(1)$ \\
\hline & $9.74(5)$ & 8 & $0.351(2)$ & 0 & $0.278(2)$ & $0.012(1)$ \\
\hline & $10.72(5)$ & 8 & $0.357(2)$ & 0 & $0.277(2)$ & $0.014(1)$ \\
\hline & $11.49(5)$ & 8 & $0.360(3)$ & 0 & $0.279(3)$ & $0.015(1)$ \\
\hline & $12.38(5)$ & 8 & $0.357(3)$ & 0 & $0.274(2)$ & $0.015(1)$ \\
\hline & $13.21(5)$ & 8 & $0.357(2)$ & 0 & $0.277(2)$ & $0.014(1)$ \\
\hline & $14.18(5)$ & 8 & $0.357(3)$ & 0 & $0.269(2)$ & $0.015(1)$ \\
\hline & $15.45(5)$ & 8 & $0.359(3)$ & 0 & $0.273(3)$ & $0.014(1)$ \\
\hline & $17.65(5)$ & 8 & $0.359(3)$ & 0 & $0.276(2)$ & $0.014(1)$ \\
\hline & $20.14(5)$ & 8 & $0.369(2)$ & 0 & $0.278(2)$ & $0.016(1)$ \\
\hline
\end{tabular}

